OPEN ACCESS

Edited by:

Girolamo Pelaia,

University of Catanzaro, Italy

Reviewed by:

Chiaki Iwamura,

Chiba University, Japan Kenta Shinoda,

National Institutes of Health $(\mathrm{NIH})$,

United States

*Correspondence:

Victoria del Pozo

vpozo@fjd.es

José A. Cañas

jose.canas@fjd.es

Specialty section:

This article was submitted to

Inflammation,

a section of the journal

Frontiers in Immunology

Received: 21 September 2020

Accepted: 23 November 2020

Published: 08 January 2021

Citation:

Cañas JA, Rodrigo-Muñoz JM,

Sastre B, Gil-Martinez M, Redondo N and del Pozo V (2021) MicroRNAs

as Potential Regulators of

Immune Response Networks in Asthma and Chronic Obstructive

Pulmonary Disease.

Front. Immunol. 11:608666. doi: 10.3389/fimmu.2020.608666

\section{MicroRNAs as Potential Regulators of Immune Response Networks in Asthma and Chronic Obstructive Pulmonary Disease}

\author{
José A. Cañas ${ }^{1,2^{*}}$, José M. Rodrigo-Muñoz ${ }^{1,2}$, Beatriz Sastre ${ }^{1,2}$, Marta Gil-Martinez ${ }^{1}$, \\ Natalia Redondo ${ }^{1}$ and Victoria del Pozo ${ }^{1,2^{*}}$ \\ 1 Immunoallergy Laboratory, Immunology Department, Instituto de Investigación Sanitaria Fundación Jiménez Díaz (IIS-FJD), \\ Madrid, Spain, ${ }^{2}$ CIBER de Enfermedades Respiratorias (CIBERES), Madrid, Spain
}

Chronic respiratory diseases (CRDs) are an important factor of morbidity and mortality, accounting for approximately $6 \%$ of total deaths worldwide. The main CRDs are asthma and chronic obstructive pulmonary disease (COPD). These complex diseases have different triggers including allergens, pollutants, tobacco smoke, and other risk factors. It is important to highlight that although CRDs are incurable, various forms of treatment improve shortness of breath and quality of life. The search for tools that can ensure accurate diagnosis and treatment is crucial. MicroRNAs (miRNAs) are small non-coding RNAs and have been described as promising diagnostic and therapeutic biomarkers for CRDs. They are implicated in multiple processes of asthma and COPD, regulating pathways associated with inflammation, thereby showing that miRNAs are critical regulators of the immune response. Indeed, miRNAs have been found to be deregulated in several biofluids (sputum, bronchoalveolar lavage, and serum) and in both structural lung and immune cells of patients in comparison to healthy subjects, showing their potential role as biomarkers. Also, miRNAs play a part in the development or termination of histopathological changes and comorbidities, revealing the complexity of miRNA regulation and opening up new treatment possibilities. Finally, miRNAs have been proposed as prognostic tools in response to both conventional and biologic treatments for asthma or COPD, and miRNA-based treatment has emerged as a potential approach for clinical intervention in these respiratory diseases; however, this field is still in development. The present review applies a systems biology approach to the understanding of miRNA regulatory networks in asthma and COPD, summarizing their roles in pathophysiology, diagnosis, and treatment.

Keywords: chronic respiratory diseases, systems biology, microRNAs, asthma, chronic pulmonary obstructive disease 


\section{INTRODUCTION}

Chronic respiratory diseases (CRDs) like asthma and chronic obstructive pulmonary disease (COPD) are complex and heterogeneous diseases that pose a challenge for investigation and management. Multiple environmental factors and genetic predisposition modulate asthma and COPD phenotypes and severity, as well as how a patient responds to treatment. In these diseases, genomics, metabolomics, epigenomics, and transcriptomics engage in intricate interaction at the cellular level. Systems biology tries to construct models or approaches throughout the network that reveal the underlying biology and help to understand living systems. Traditionally, gene modulation and cell-signaling networks have been thought to be the main regulatory systems in cells, and RNAs have been considered molecules that only codify genetic information to protein synthesis. However, this idea is changing due to the recent advances in non-coding RNAs, such as microRNAs (miRNAs) (1). MiRNAs are 18-22 nucleotides in length and block protein translation by RNA-miRNA interaction (2). These small RNAs regulate hundreds to thousands of genes, offering a broad combinatorial possibility and constituting complicated regulatory networks. As a result, systems biology approaches are essential to understand miRNAs functions in complex diseases such as asthma and COPD, combining data from high-throughput experiments with computational models for performance of data driven modeling and model driven experimental methods (Figure 1).

New procedures have been applied in this topic, particularly to determine the coordinate function of miRNAs in cancer. Lai et al. used a systems biology approach to unravel the role of miRNAs therapeutics in this disease $(3,4)$. This approach highlights the importance of high-throughput experiments to determine from the same biological experiments the transcriptome of miRNAs and their gene targets, with further exploration by proteomic data, or immunoprecipitation-based analysis, as this is very helpful in validating the huge amount of predicted miRNA-gene interactions detected in silico by diverse bioinformatic tools reviewed by Gomes et al. (5). After getting this data, then it is easier to apply computational biology approaches, most of them based on previously validated data for gene-miRNA interaction determination. After this, system biology comes in, because as previously stated it helps in creating maps of miRNA-gene-pathway interactions that may have an actual function in cell physiology (6). The actual mapping can

\footnotetext{
Abbreviations: $\alpha$-SMA, alpha-smooth muscle actin; ACO, Asthma-COPD overlapping; ASMC, airway smooth muscle cells; AUC, area under curve; BALF, bronchoalveolar lavage fluid; COPD, chronic obstructive pulmonary disease; COX-2. cyclooxygenase-2; CRDs, chronic respiratory diseases; CSE, cigarette smoke extract; FEV1, forced respiratory volume in the first second; GCs, glucocorticoids; HBECs, human bronchial epithelial cells; HDAC, histone deacetylase; HIF-1 $\alpha$, hypoxia-inducible factor 1-alpha; ICS, inhaled corticosteroid; IFN- $\gamma$, interferon gamma; IL, interleukin; lncRNA, longnoncoding RNA; MAPK, mitogen-activated protein kinase; miRNAs, microRNAs; PBMCs, peripheral blood mononuclear cells; PGE2, prostaglandin E2; PI3K, phosphatidylinositol 3-kinase; ROS, reactive oxygen species; TGF, transforming growth factor; TLR, Toll-like receptor; TNF, tumor necrosis factor.
}

be further detailed by introducing the regulation that occurs on the controllers (miRNAs) themselves, as we have to take into account miRNA biogenesis and structure, epigenetics, epitranscriptomics, transcription factor circuits and super enhancers, all of them modulating miRNAs functions in diseases (7).

In this review, we will focus on asthma and COPD, two of the most common CRDs worldwide, providing an overview about those molecular pathology mechanisms by miRNAs. Additionally, we will explore new insights in the field of miRNAs as biomarkers of these diseases. Lastly, we will highlight altered after specific treatment for each disease and discuss clinical advances in the use of miRNAs. With this review we want to set the foundations of actual data of miRNAs as regulators and biomarkers of chronic respiratory diseases, being able to serve as a guide for future application of complex system biology approaches to determine the actual combined effects of this miRNAs in these diseases, seeing the big picture of the pathophysiology.

\section{PATHOPHYSIOLOGY OF ASTHMA AND COPD}

CRDs are an important cause of morbidity and mortality worldwide. According to the World Health Organization, the most common CRDs are asthma, COPD, lung hypertension, and occupational lung diseases (8). It is estimated that more than 300 million people worldwide have asthma and 3 million people die each year from COPD, accounting for an estimated $6 \%$ of total deaths globally (8).

The causes triggering the development of CRDs are diverse. Asthma is a multifactorial and heterogeneous disease, and a variety of risk factors have been linked to this disease such as genetics, atopy, and recurrent viral infections (9). Additionally, tobacco has been described as the main cause of COPD, though exposure to other toxic substances such as air pollution originated from biomass fuel has been also linked to $\operatorname{COPD}(10,11)$. Independently of origin, CRDs are characterized by the inflammation and obstruction of the lower respiratory tract due to a hyperresponse of the immune system accompanied by cellular infiltration $(12,13)$. In allergic asthma, the predominant leucocytes are eosinophils, with a triggered type 2 immune response with high abundance of interleukin (IL)-4, IL-5, and IL-13 (14, 15); however, in COPD the most abundant cellular populations are neutrophils, macrophages, and T lymphocytes $(11,13)$.

Asthma presents with high variability among patients, thus posing a challenge for the improvement of diagnostic and therapeutic tools (16). Asthma is characterized by chronic airway inflammation, mucus hypersecretion, and bronchial hyperresponsiveness and the presence of respiratory symptoms such as wheezing, shortness of breath, chest tightness, and cough (17). Airway inflammation and structural remodeling together with reversible airflow obstruction and airway hyperreactivity are the main distinctive findings of asthmatic disease (18). In addition, asthma encompasses several disease variants, meaning that it can 


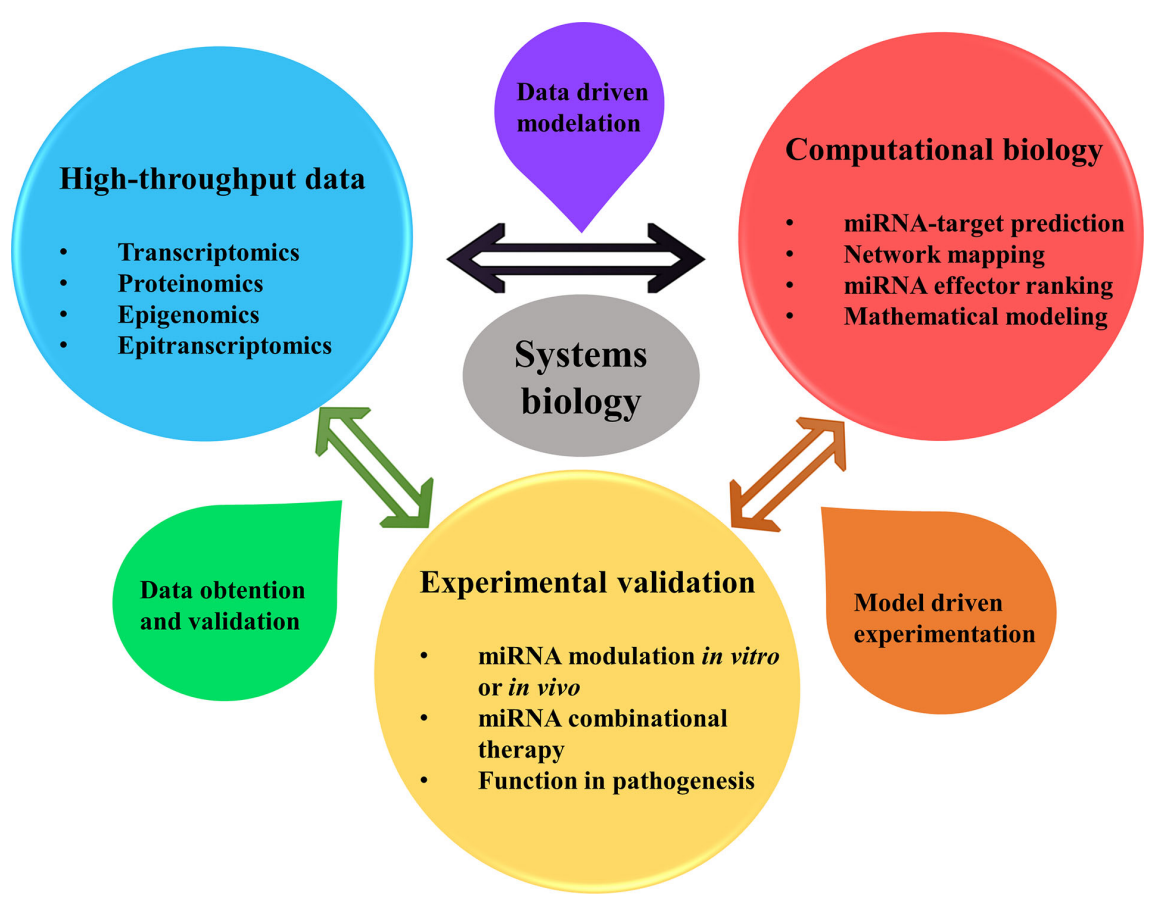

FIGURE 1 | Systems biology approaches allow for better understanding the roles of miRNAs in pathophysiology, diagnosis, and treatment of asthma and COPD. Being miRNAs regulators of multiple genes expression affecting thus several pathways simultaneously, a comprehension of the global picture of their regulation is in need. System biology approach helps in this matter, by using a data driven method for creating computational models from previous data of high-throughput experimentation (transcriptomics, proteomics, epigenomics and epitranscriptomics) that could be obtained from the literature. Network mapping modeling allows determining the interaction between miRNAs, genes (or proteins) and phenotype and clinical data. Besides, mathematical models can help finding key miRNAs with power to alter the core of cellular pathway regulation and performance. After this, model driven experimentation allows to confirm the predicted targeting by miRNAs in cooperation by their modulation in vivo or in vitro, uncovering their role in the disease and their use in therapy. Finally, this new data obtained and validated can be summed up to confirm previous high-throughput results, enlarging the available data of miRNA regulation in asthma or COPD.

be stratified into several phenotypes and endotypes. Phenotyping and endotyping of asthma with the use of induced sputum or peripheral blood cytology can facilitate responsiveness to treatment, specify the pathogenic mechanisms, and anticipate risks. These features attest to the complexity of asthmatic disease and the numerous factors involved in its pathophysiology, suggesting that systems biology can aid in understanding the key factors implicated in molecular networks.

COPD is a multifactorial and heterogeneous disease that affects millions of people worldwide (19). This pathology is a major cause of chronic morbidity and mortality, and many people bear the burden of this disease for years. COPD encompasses small airway obstruction, emphysema, and chronic bronchitis, and it is characterized by chronic inflammation of the airways and lung parenchyma with progressive and irreversible airflow limitation (20). Symptoms include dyspnea, cough, and sputum production (21). The phenotypic characterization of COPD patients may allow for better risk stratification and personalization of therapy (22). Airway damage in COPD is triggered by dust, fumes, vapors, or gas, but the primary factor is exposure to tobacco smoke (23). Cigarette smoke alters both innate and adaptive immunity by upregulating cytokines (IL-1, IL-6, IL-8, tumor necrosis factor [TNF]- $\alpha \ldots)(24,25)$, and modifying the physiological function of alveolar macrophages (26), dendritic cells (27), neutrophils (28), and natural killer cells (29). Smoking also modifies the behavior of the epithelium by increasing mucin production (MUC5AC) (30) and disrupting epithelial cell-cell junctions, thus increasing the permeability of the epithelial barrier (31).

It has been shown that besides altering the normal physiology of the airways, cigarette smoke may change the epigenetic landscape, and these changes can be passed on to future generations through inheritance (32). Several studies show that COPD causes certain epigenetic changes in the lungs $(33,34)$, and many of these changes are likely due to tobacco smoke exposure (35), such as F2RL3 methylation, which is associated with smoking behavior and high mortality $(7,36)$. These epigenetic changes can be targeted as a possible therapy; current genetic editors like zinc-finger nucleases and CRISPRCas9 can be coupled to them and enzymes to rewrite epigenetic markers induced by tobacco smoke or related to COPD pathophysiology $(37,38)$.

\section{MiRNAs IN LUNG DISEASES}

The complex interplay between genetics, epigenetics, protein synthesis, and immune response in asthma and COPD is actually even more intricate when another layer of regulation is introduced: 
miRNAs. These small molecules or noncoding RNAs are capable of regulating the gene-protein expression of immune system performance (39) and structural airway homeostasis and function (40). Moreover, miRNAs can regulate epigenetic modulators and be regulated by epigenetic changes as well (41). MiRNAs are therefore essential players in the physiopathology of both diseases, creating complex networks and interactions among diverse factors (genes, proteins, cells) that play a role in these pathologies (Figure 2).

It is important to differentiate between two kinds of miRNAs: intracellular and extracellular (found inside extracellular vesicles such as exosomes, microvesicles, and apoptotic bodies) (42). Intracellular miRNAs regulate several cellular pathways, and their expression is tissue- and disease-specific, so they have been widely used as prognostic and diagnostic biomarkers of different pathologies, including viral infections, cancer, cardiovascular and allergic diseases $(43,44)$. Also, circulating miRNAs have been studied and used as biomarkers due to their molecular properties (resistance to degradation and ubiquity) (45).

\section{MiRNAs as Asthma Biomarkers}

Circulating cell-free miRNAs can be found in serum or plasma incorporated into extracellular vesicles, such as exosomes, and in ribonucleoprotein complexes. There are many studies showing miRNA deregulation in asthmatic patients (Table 1). It is known that several miRNAs are increased in serum samples including miR-21, miR-145, miR-146a, and miR-338, among others (45, 70). Likewise, other authors have described downregulation of other serum miRNAs, such as miR-18a, miR-126, and miR-155 (71). However, due to the complex relation between miRNAs and genes (a single miRNA can regulate hundreds of genes), not all miRNAs qualify for use as biomarkers. One solution to this problem may be to use combinations of several miRNAs or a specific miRNA profile to achieve good sensitivity, specificity, and positive and negative predictive values.

In 2016, Panganiban et al. established a differential miRNA profile among asthmatic patients, non-asthmatic patients with allergic rhinitis, and non-asthmatic non-allergic subjects (45). In their study, the researchers found 30 miRNAs in plasma that were differentially expressed among three groups, showing six miRNAs (miR-125b, miR-16, miR-299-5p, miR-126, miR-206, and miR-133b) with a high predictive value when differentiating allergic and asthmatic status. Moreover, some of these circulating miRNAs grouped asthmatic patients into two clusters according to the number of peripheral blood eosinophils. Finally, they

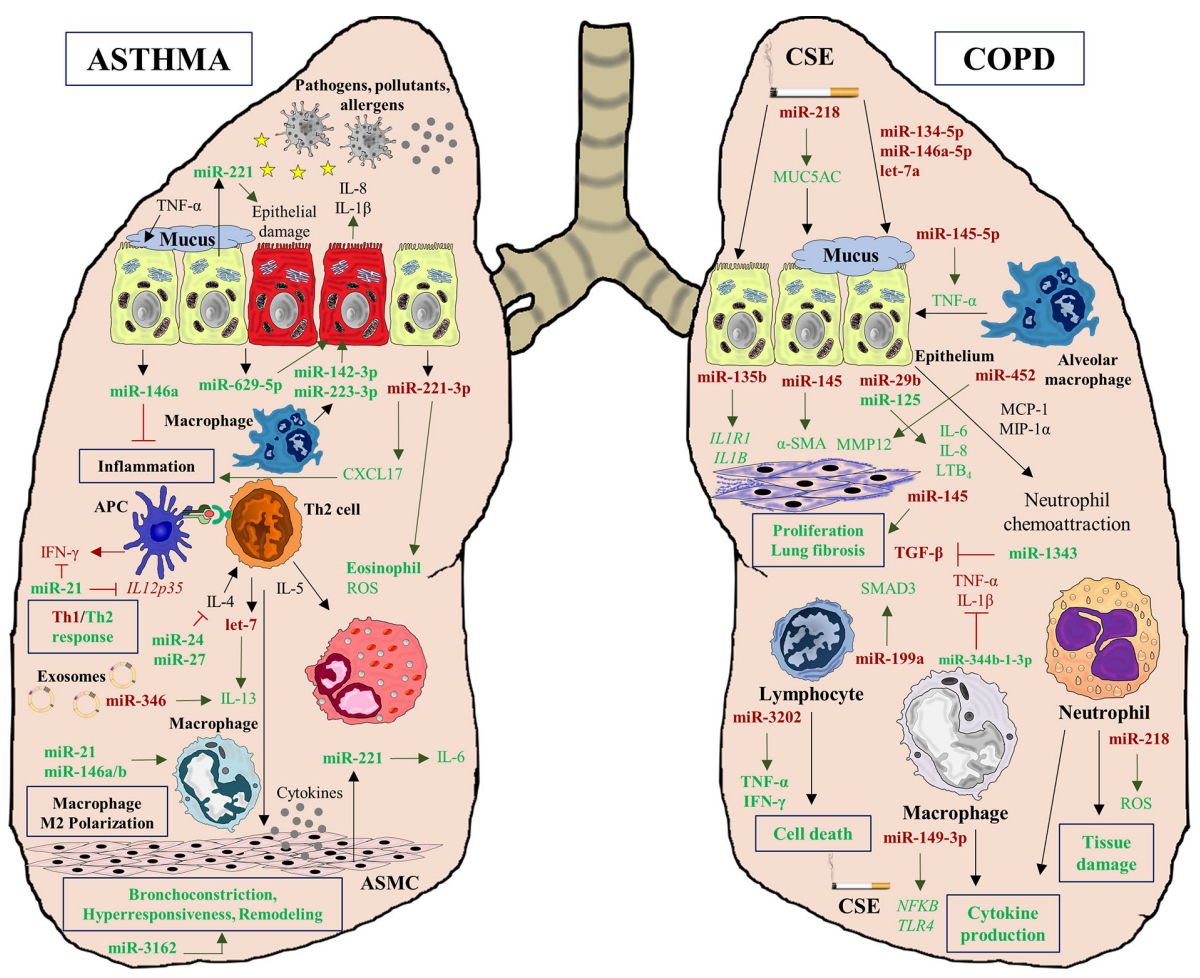

FIGURE 2 | MiRNA interactions in asthma and COPD diseases. MiRNAs play a crucial role, regulating multiples processes characteristics of both pathologies. In asthma, deregulation of multiples miRNAs affects to inflammatory processes (miR-221-3p), Th1/Th2 response imbalance (miR-21), cytokine production (miR-629-5p, miR-142-3p, and miR-223-3p), epithelial injury (miR-221), macrophage polarization to M2 phenotype (miR-146a/b, miR-21) and airway remodeling (miR-3162). However, miRNAs also can alleviate inflammation (miR-146a) and cytokine decrease production (miR-24 and miR-27). In COPD pathogenesis, miRNAs can be altered by CSE exposition and they are involved in mucus hypersecretion (miR-218) and cytokine production (miR-149-3p). Moreover, several deregulated miRNAs are implicated in lung fibrosis (miR-135b, miR-145, and miR-452), and in tissue damage (miR-218). Similarly to asthma, in COPD some miRNAs can act as regulators of inflammation decreasing the secretion of several cytokines such as TGF- $\beta$ (miR-1343), TNF- $\alpha$, and IL-1 $\beta$ (miR-344b-1-3p). 
TABLE 1 | List of miRNAs involved in asthma pathogenesis.

\begin{tabular}{|c|c|c|c|c|c|}
\hline miRNA & Implication & Origin & Expression & Target Gene/Pathway & References \\
\hline $\begin{array}{l}\text { miR- } \\
140-3 p\end{array}$ & $\begin{array}{l}\text { CD38 expression, chemokine regulation, } \\
\text { inflammation and ASMC proliferation in asthma }\end{array}$ & ASMC & Downregulated & CD38, CCL11, CXCL12, CXCL10, CCL5, CXCL8 & $(46,47)$ \\
\hline$m i R-145$ & ASMC proliferation and migration & & Upregulated & $K L F 4$ & $(48)$ \\
\hline $\begin{array}{l}\text { miR- } \\
146 a-5 p\end{array}$ & Mucus production & & Downregulated & UBD, CXCL10, CXCL8, CCL20, UCA1 & (49) \\
\hline $\operatorname{miR}-638$ & ASMC proliferation and migration & & Upregulated & NR4A3, CCND1 & (50) \\
\hline $\operatorname{miR}-708$ & $\begin{array}{l}\text { CD38 expression, chemokine regulation, } \\
\text { inflammation and ASMC proliferation in asthma }\end{array}$ & & Downregulated & $\begin{array}{l}\text { CD38, CCL11, CXCL10, CCL2, CXCL8, JNK, } \\
\text { MAPK, PTEN/AKT signaling pathways }\end{array}$ & $(47,51)$ \\
\hline $\begin{array}{l}\mathrm{miR}- \\
146 a / b\end{array}$ & $\begin{array}{l}\text { Regulation of inflammation, macrophage M2 } \\
\text { polarization }\end{array}$ & $\begin{array}{l}\text { Epithelial cells, } \\
\text { macrophages }\end{array}$ & Upregulated & PTGS2, IL1B, NOTCH5 & $(52-56)$ \\
\hline $\begin{array}{l}\text { let-7 } \\
\text { family }\end{array}$ & Asthma biomarker & $\begin{array}{l}\text { BALF-derived } \\
\text { exosomes }\end{array}$ & Downregulated & & $(57)$ \\
\hline$m i R-126$ & Asthma progression & & Upregulated & DNMT1 & (58) \\
\hline $\begin{array}{l}\text { miR-200 } \\
\text { family }\end{array}$ & Asthma biomarker & & Downregulated & & $(57)$ \\
\hline miR-346 & Airway inflammation, $T$ helper cell differentiation & & Downregulated & IL13 & (59) \\
\hline $\begin{array}{l}\text { miR- } \\
574-5 p\end{array}$ & & & Downregulated & IL5RA & (59) \\
\hline let-7 & Regulation of asthmatic hyperresponse & Lung & Upregulated & IL13 & $(60)$ \\
\hline miR-24 & Cytokine regulation & & Upregulated & IL-4 production pathway & (61) \\
\hline miR-27 & & & Upregulated & GATA3 & (61) \\
\hline $\operatorname{miR}-16$ & Asthma biomarker & Plasma & Upregulated & & $(45)$ \\
\hline $\begin{array}{l}\mathrm{miR}- \\
125 \mathrm{~b}\end{array}$ & & & Upregulated & & $(45)$ \\
\hline $\begin{array}{l}\text { miR- } \\
133 b\end{array}$ & & & Downregulated & & $(45)$ \\
\hline miR-206 & & & Upregulated & & $(45)$ \\
\hline $\begin{array}{l}\operatorname{miR}- \\
144-5 p\end{array}$ & Asthma biomarker & Serum & Upregulated & & $(43)$ \\
\hline $\operatorname{miR}-155$ & & & Upregulated & & $(62)$ \\
\hline $\begin{array}{l}\text { miR- } \\
185-5 p\end{array}$ & & & Upregulated & & $(43)$ \\
\hline $\begin{array}{l}\mathrm{miR}- \\
320 \mathrm{a}\end{array}$ & & & Upregulated & & $(43)$ \\
\hline $\begin{array}{l}\text { miR- } \\
1246\end{array}$ & & & Upregulated & & $(43)$ \\
\hline $\begin{array}{l}\text { miR- } \\
485-5 p\end{array}$ & Pediatric asthma & & Upregulated & SPRED2 & (63) \\
\hline $\begin{array}{l}\text { miR- } \\
3162-3 p\end{array}$ & & & Upregulated & CTNNB1 & $(64)$ \\
\hline $\mathrm{miR}-221$ & Pediatric asthma, Epithelial cell injury & $\begin{array}{l}\text { Serum, epithelial } \\
\text { cells }\end{array}$ & Upregulated & SPRED, SIRT1 & $(63,65)$ \\
\hline miR-21 & $\begin{array}{l}\text { Imbalance Th1/Th2 response, macrophage M2 } \\
\text { polarization }\end{array}$ & $\begin{array}{l}\text { Serum, lung, } \\
\text { macrophage }\end{array}$ & Upregulated & IL12p3, IRF5, CSF1R & $\begin{array}{l}(43,52,54 \\
62,66,67)\end{array}$ \\
\hline $\begin{array}{l}\text { miR- } \\
142-3 p\end{array}$ & Neutrophilic asthma & Sputum & Upregulated & $\begin{array}{l}\text { MAPK, NOD-like receptor, Toll-like receptor, JAK- } \\
\text { STAT, and the TGF- } \beta \text { signaling pathways }\end{array}$ & (68) \\
\hline $\begin{array}{l}\text { miR- } \\
223-3 p\end{array}$ & & & Upregulated & & (68) \\
\hline $\begin{array}{l}\text { miR- } \\
629-3 p\end{array}$ & & & Upregulated & & (68) \\
\hline $\begin{array}{l}\mathrm{miR}- \\
221-3 p\end{array}$ & $\begin{array}{l}\text { Regulation of eosinophil counts and ROS } \\
\text { production }\end{array}$ & & Downregulated & CXCL17 & (69) \\
\hline
\end{tabular}

demonstrated that circulating miRNAs could be used to diagnose both allergic rhinitis and asthmatic patients and characterize asthma subtypes. Milger et al., in 2017, identified some possible plasma miRNA candidates as biomarkers in a murine model of asthma (72). These miRNAs were validated in a different cohort of healthy subjects and asthmatic patients, using a regularized logistic regression model to identify five miRNA ratios that are able to differentiate allergic asthmatics from controls with an area under the curve (AUC) of 0.92. However, this miRNA signature did not differentiate asthma sub-phenotypes.

Our group recently described an eosinophil miRNA profile for asthma diagnosis based on statistical models (43). First, we described a miRNA signature from peripheral blood eosinophils, which is able to differentiate asthmatic subjects from healthy controls. Among deregulated miRNAs, we found upregulation of miR-21 and miR-146a/b, which have been associated with 
asthma and allergic diseases (73). In addition, this molecular profile grouped the asthmatic population into two principal clusters, which are distinguishable by the number of peripheral blood eosinophils and serum periostin levels. Then, we evaluated these miRNAs in serum and found that miR-1246, miR-144-5p, miR-320a, miR-185-5p, and miR-21-5p were upregulated in asthmatic patients. Specifically, miR-185-5p was related to asthma severity. Combination of miR-185-5p, miR-144-5p, and miR-1246 in a logistic regression model distinguished healthy individuals from asthmatics with an AUC of 0.86 , and a specificity and sensitivity of 0.89 and 0.77 , respectively. Serum expression of miR-320a, miR-185-5p, and miR-144-5p was used to classify subjects into different asthma disease phenotypes (intermittent, mild persistent, moderate persistent, and severe persistent) in a random forest model, showing that miRNAs can be used for asthma diagnosis and severity classification. Unfortunately, to date no more studies about specific miRNAs of eosinophils have been conducted, making this is a field of potential research focus.

Elkashef et al. have reported the use of miR-21 and miR155 as biomarkers in bronchial asthma (62). They showed that both miRNAs are higher in serum of individuals with eosinophilic asthma than healthy subjects. Through a receiver operating characteristic curve with both miRNAs, the authors obtained high values for sensitivity, specificity, and AUC. Thus, they proposed that these miRNAs could be used as non-invasive biomarkers in asthma diagnosis and response to therapy.

As mentioned previously, another important factor in asthma pathogenesis is the role that exosomes exert in the disease (74). These particles are nanovesicles, with a diameter of 30-150 nm, and their main role is linked to intercellular communication. It is worth highlighting that these small vesicles contain miRNAs in addition to DNA, proteins, and lipid mediators. Thus, some circulating miRNAs have been associated with exosomes and it has been observed that these exosomal miRNAs play a critical role in asthma pathogenesis $(75,76)$.

It is important to take into account that exosomes can be located in multiple biological fluids including serum, sputum, bronchoalveolar lavage fluid (BALF), urine, breast milk, etc., and that exosomes are associated with multiple pathological processes, including asthma (16). In 2013, Levänen et al. found significant differences in a set of exosomal miRNAs from BALF between mild asymptomatic asthmatic patients and healthy subjects, including miRNAs of the let-7 and miR-200 families (57). Later, Gon et al. showed 139 exosomal miRNAs from BALF deregulated in a house-dust mite murine model compared to control mice (59). Also, they observed that 54 altered miRNAs were common between exosomes and lung tissues. Using computational analysis, the authors then found that 31 genes were the targets of these miRNAs, including important genes in asthma pathogenesis such as IL13 and IL5RA.

Different studies have been conducted in exosomes from serum $(58,77)$. These showed that several miRNAs, including miR-125b and miR-126, were altered in these nanovesicles between asthma condition and normal status. According to the authors, these results can be applied to the use of novel diagnostic strategies.

\section{Sputum miRNAs Characterize the Inflammatory Focus}

While it is clear that serum/plasma miRNAs are good noninvasive biomarkers, miRNAs from sputum samples could also be used as diagnostic tools. However, the number of studies in this field reduced drastically and only a few research articles address this topic (Table 1). One of them was performed in 2018, conducted by Zhang et al. (69). In this study, the authors found that sputum and plasma miR-221-3p levels were significantly decreased in asthmatics compared with healthy subjects. Furthermore, there was a positive correlation between plasma and induced sputum miR-221-3p levels and values of this miRNA in epithelial cells, just like a negative correlation with the eosinophil percentage in sputum, the number of eosinophils in bronchial biopsies, and fraction of exhaled nitric oxide levels. The study highlighted that sputum miR-221-3p levels were increased in asthmatic patients after 4 weeks of inhaled corticosteroid (ICS) treatment, compared with asthmatic patients at baseline. With these data, the researchers proposed that sputum miR-221-3p could be used as a biomarker for airway eosinophilic inflammation and response to treatment. In another study performed in 2016, Maes et al. showed a different miRNAs profile in sputum samples among healthy subjects, patients with mild-to-moderate asthma, and patients with severe asthma (68). They presented three miRNAs that were increased in sputum samples from patients with severe asthma, which are related to neutrophilic asthma phenotype (Table 1).

\section{MiRNAs for Characterization of COPD}

Study of miRNAs has been rapidly extended to respiratory diseases including COPD, likely due to research showing that cigarette smoke acts as a modulator of miRNA regulation in samples such as lung tissue $(78,79)$, serum $(80)$ and sputum (81) (Table 2). Therefore, similarly to asthma, there are miRNAs that can serve as biomarkers for COPD against healthy conditions in different biofluids. MiRNAs also regulate the expression of genes in COPD. Several miRNAs have been implicated in the physiopathology of COPD $(89,149)$. However, it is also important to mention that some miRNAs are also related to protective functions in COPD pathology when induced by treatment (144).

Related to lung function, some miRNAs have shown correlation with worse pulmonary function values in COPD, some of them being directly correlated with forced expiratory volume in the first second $\left(\mathrm{FEV}_{1}\right)$ values $(81,104,106,130)$; while others, correlate negatively $(96,125)$; and even, in other cases, present a negative correlation with FEV1/FVC ratio (97, 113, 122) (Table 2).

Regarding characteristic processes of COPD, fibrosis is almost the main pathological event that occurs in this disease. MiR-1343 reduce transforming growth factor (TGF)- $\beta$ receptors I and II, SMAD2 and SMAD3, which are fibrotic factors (150), whereas miR-145 may have profibrotic effects, inducing differentiation of 
TABLE 2 | List of miRNAs involved in COPD pathogenesis and diagnosis.

\begin{tabular}{|c|c|c|c|c|c|}
\hline miRNA & Implication & Origin & Expression & Target Gene/Pathway & References \\
\hline $\operatorname{miR}-452$ & $\begin{array}{l}\text { Control of airway } \\
\text { inflammation and } \\
\text { remodeling }\end{array}$ & Alveolar macrophages & Downregulated & MMP12 & $(82)$ \\
\hline miR-344b-1-3p & $\begin{array}{l}\text { Modulator of the immune } \\
\text { responses by CSE }\end{array}$ & & Upregulated & $T L R 2$ & (83) \\
\hline miR-637 & $\begin{array}{l}\text { Development of } \\
\text { pulmonary hypertension }\end{array}$ & Artery smooth muscle cells & Downregulated & CDK6 & $(84)$ \\
\hline miR-197 & $\begin{array}{l}\text { Vascular remodeling and } \\
\text { contraction }\end{array}$ & & Downregulated & E2F1 & (85) \\
\hline $\begin{array}{l}\text { mir-106a-363 and } \\
-106 b \text { cluster }\end{array}$ & $\begin{array}{l}\text { COPD diagnosis and } \\
\text { severity }\end{array}$ & BALF, plasma, leukocytes & $\begin{array}{l}\text { Upregulated/ } \\
\text { downregulated }\end{array}$ & $\begin{array}{l}\text { AKT1, PTEN, MYD88, IRAK4, IL6, } \\
\text { TGF- } \beta R\end{array}$ & (86-88) \\
\hline $\mathrm{miR}-146 \mathrm{a}$ & $\begin{array}{l}\text { Inflammation and mucus } \\
\text { secretion }\end{array}$ & $\begin{array}{l}\text { BECs, fibroblasts, } \\
\text { macrophages, plasma, lung } \\
\text { tissue }\end{array}$ & $\begin{array}{l}\text { Upregulated/ } \\
\text { downregulated }\end{array}$ & $\begin{array}{l}\text { IRAK1/TRAF6, PGE2, COX2, } \\
\text { PDE7A, IL-1R kinase-1 }\end{array}$ & $(52,89-95)$ \\
\hline miR-195 & $\begin{array}{l}\text { Cytokine production and } \\
\text { inflammation }\end{array}$ & BECs, lung tissue & Upregulated & PHLPP2 & $(96)$ \\
\hline $\operatorname{miR}-132$ & $\begin{array}{l}\text { Direct correlation to } \\
\text { FEV1/FVC\% }\end{array}$ & BECs, monocytes, serum & Upregulated & SOCS5 & $(97)$ \\
\hline Profile of 9 miRNAs & $\begin{array}{l}\text { Lung cancer prediction in } \\
\text { COPD patients }\end{array}$ & Blood cells & Downregulated & $\begin{array}{l}\text { SRCAP, DCTN5, ULK } 1 \text {, and } \\
\text { SEMA7A }\end{array}$ & $(98)$ \\
\hline $\operatorname{miR}-183(-5 p)$ & $\begin{array}{l}\text { Increases disease } \\
\text { severity and } \\
\text { pathogenesis }\end{array}$ & $\begin{array}{l}\text { Blood, lungs, smooth muscle } \\
\text { cells, leukocytes }\end{array}$ & $\begin{array}{l}\text { Upregulated/ } \\
\text { downregulated }\end{array}$ & $\begin{array}{l}\text { BKCaß1, Autophagy, TLR, NSCLC, } \\
\text { cardiomyopathy }\end{array}$ & $(88,99)$ \\
\hline Profile of 5 miRNAs & $\begin{array}{l}\text { Differentiating healthy, } \\
\text { asthma and COPD }\end{array}$ & Breath exhaled condensate & Downregulated in asthma & $\begin{array}{l}\text { IL-13, IL-5, GATA3, FCe R1 } \beta, I L-1 \\
\beta, \text { MMP-1, Mucin-1 }\end{array}$ & $(100)$ \\
\hline miR-29b & $\begin{array}{l}\text { Regulation of cytokine } \\
\text { expression }\end{array}$ & Bronchial epithelial cells & Downregulated & $B R D 4$ & $(101)$ \\
\hline miR-10a-5p & $\begin{array}{l}\text { Pathobiology of COPD } \\
\text { and asthma }\end{array}$ & & Upregulated & FOXO3 and PDE7A & $(94)$ \\
\hline $\begin{array}{l}\text { miR-132-212, }-17-92 \\
-192-194 \text { clusters }\end{array}$ & $\begin{array}{l}\text { COPD diagnosis against } \\
\text { lung cancer }\end{array}$ & BALF & Downregulated & $\begin{array}{l}\text { AKT1, ERBB2, KRAS, PTEN, } \\
\text { MYD88 }\end{array}$ & $(87)$ \\
\hline miR-191 & $\begin{array}{l}\text { Endothelial injury and } \\
\text { inflammation }\end{array}$ & $\begin{array}{l}\text { Circulating endothelial } \\
\text { microparticles released by } \\
\text { CSE }\end{array}$ & Upregulated & & $(102)$ \\
\hline miR-638 & $\begin{array}{l}\text { Regulation of oxidative } \\
\text { stress response }\end{array}$ & Emphysematous lung tissue & Upregulated & ADAM15, HDAC5, APBB1 & (103) \\
\hline miR-126 & $\begin{array}{l}\text { Endothelial injury and } \\
\text { inflammation }\end{array}$ & $\begin{array}{l}\text { Endothelial microparticles, } \\
\text { ECs, UVECs }\end{array}$ & $\begin{array}{l}\text { Upregulated/ } \\
\text { downregulated }\end{array}$ & ATM protein kinase & $(102,104)$ \\
\hline$m i R-125 a(-5 p), 125 b$ & $\begin{array}{l}\text { Inflammation, severity } \\
\text { and AECOPD }\end{array}$ & $\begin{array}{l}\text { Endothelial microparticles, } \\
\text { leukocytes, sputum, plasma }\end{array}$ & Upregulated & $\begin{array}{l}\text { Autophagy, TLR, NSCLC, } \\
\text { cardiomyopathy }\end{array}$ & $\begin{array}{c}(81,88,102 \\
105)\end{array}$ \\
\hline miR-503 & $\begin{array}{l}\text { Correlate with pulmonary } \\
\text { function (FEV1) }\end{array}$ & Lung fibroblasts & Downregulated & VEGF & $(106)$ \\
\hline miR-335-5p & $\begin{array}{l}\text { Modification of fibroblast } \\
\text { behavior and function }\end{array}$ & & Downregulated & $R b 1, C A R F$, and SGK3 & $(107)$ \\
\hline$m i R-31-5 p$ & $\begin{array}{l}\text { Regulator of mucus } \\
\text { hypersecretion }\end{array}$ & Lung tissue & Upregulated & ST3GAL2, PITPNM2, ARHGEF15 & $(108)$ \\
\hline $\operatorname{miR}-1274 a,-424$ & Emphysema and fibrosis. & $\begin{array}{l}\text { Lung tissue and bronchial } \\
\text { epithelial cells }\end{array}$ & Upregulated & $\begin{array}{l}\text { IL-6, TEP1, CAT, TGF } \beta \text {, and WNT } \\
\text { pathway }\end{array}$ & $(79)$ \\
\hline miR-134-5p & $\begin{array}{l}\text { Chronic mucus } \\
\text { hypersecretion } \\
\text { homeostasis }\end{array}$ & & Downregulated & KRAS & (90) \\
\hline $\operatorname{miR}-150$ & $\begin{array}{l}\text { Suppression of CSE- } \\
\text { induced inflammation }\end{array}$ & & Downregulated & P53 & $(109)$ \\
\hline miR-223 & $\begin{array}{l}\text { Emphysema, fibrosis, } \\
\text { immunity }\end{array}$ & Lung tissue, BECs & Upregulated & $\begin{array}{l}\text { IL-6, TEP1, CAT, TGF } \beta, \text { WNT, } \\
\text { HDAC2 }\end{array}$ & $(79,110)$ \\
\hline let-7 family $(a, c, d)$ & $\begin{array}{l}\text { Mucus, inflammation, } \\
\text { malignancy }\end{array}$ & $\begin{array}{l}\text { Lung tissue, BECs, BEC, } \\
\text { sputum, serum }\end{array}$ & $\begin{array}{l}\text { Upregulated/ } \\
\text { downregulated }\end{array}$ & $\begin{array}{l}\text { EDN1, IL-13, TGF- } \beta R, \text { TLR4, c- } \\
\text { myc, TNFR- /I }\end{array}$ & $\begin{array}{c}(78,81,90,100 \\
102,111,112)\end{array}$ \\
\hline $\operatorname{miR}-21$ & $\begin{array}{l}\text { Lung function, } \\
\text { inflammation, CRD } \\
\text { differentiation }\end{array}$ & $\begin{array}{l}\text { Lung tissue, BECs, } \\
\text { exosomes, serum, plasma, } \\
\text { BEC }\end{array}$ & $\begin{array}{l}\text { Upregulated/ } \\
\text { downregulated }\end{array}$ & $\begin{array}{l}\text { GF- } \beta / \text { Smad, PTEN, PI3K/HDAC2, } \\
\text { Notch1, IL-13R, STAT3, IL-1 } \beta\end{array}$ & $\begin{array}{c}(95,100,113- \\
119)\end{array}$ \\
\hline miR-101 & $\begin{array}{l}\text { Mucus homeostasis and } \\
\text { inflammation }\end{array}$ & Lung tissue, macrophages & Upregulated & $M K P-1$ & $(120)$ \\
\hline
\end{tabular}


TABLE 2 | Continued

\begin{tabular}{|c|c|c|c|c|c|}
\hline miRNA & Implication & Origin & Expression & Target Gene/Pathway & References \\
\hline miR-218 (-5p) & $\begin{array}{l}\text { Malignant transformation, } \\
\text { lung function }\end{array}$ & Lung tissue, BECs, serum & $\begin{array}{l}\text { Downregulated/ } \\
\text { upregulated }\end{array}$ & BMI1, TNFR1 & $(121-124)$ \\
\hline miR-199a-5p & $\begin{array}{l}\text { Negative correlation with } \\
\text { pulmonary function }\end{array}$ & Lung tissue, PASMCs, Treg & $\begin{array}{l}\text { Upregulated/ } \\
\text { downregulated }\end{array}$ & HIF-1 $\alpha$, SMAD3, TGF- $\beta$ pathway & $(125-127)$ \\
\hline miR-146b & $\begin{array}{l}\text { Regulating innate } \\
\text { macrophage responses }\end{array}$ & Macrophages & Upregulated & STAT1 & $(53)$ \\
\hline $\begin{array}{l}\text { profile of } 8 \text { miRNAs } \\
\text { including miR-135b }\end{array}$ & $\begin{array}{l}\text { Diagnosing AECOPD, } \\
\text { inflammation }\end{array}$ & PBMCs, BECs & Upregulated & $I L-1 R 1$ and IL-1 $\beta$ & $(128,129)$ \\
\hline $\begin{array}{l}m i R-1273 g-3 p,-24- \\
3 p,-93-5 p\end{array}$ & $\begin{array}{l}\text { Correlated with } \\
\text { pulmonary function } \\
\text { (FEV1) }\end{array}$ & Peripheral mononuclear cells & Downregulated & $\begin{array}{l}\text { IL18, IL1B, TNF, NFKBIA, CCL3, } \\
\text { and CCL4 }\end{array}$ & $(130)$ \\
\hline Profile of 5 miRNAs & $\begin{array}{l}\text { Differentiation of COPD } \\
\text { and asthma }\end{array}$ & Plasma & $\begin{array}{l}\text { Different expression } \\
\text { between COPD and } \\
\text { asthma }\end{array}$ & Interferon-gamma inducible & $(131)$ \\
\hline Profile of 9 miRNAs & Differentiation of COPD & $\begin{array}{l}\text { Plasma and airway epithelial } \\
\text { cell EVs }\end{array}$ & $\begin{array}{l}5 \text { upregulated and } 4 \\
\text { downregulated }\end{array}$ & $\begin{array}{l}\text { Inflammation, extracellular matrix } \\
\text { and remodeling }\end{array}$ & $(132)$ \\
\hline miR-206 & $\begin{array}{l}\text { Apoptosis, atrophy, } \\
\text { inflammation }\end{array}$ & $\begin{array}{l}\text { pvASMCs, limb tissue, } \\
\text { fibroblasts }\end{array}$ & Upregulated & $\begin{array}{l}\text { Notch3, VEGF, HDAC3, HDAC4, } \\
\text { IGF-1, SIRT-1, IRAK1 }\end{array}$ & $(133-135)$ \\
\hline miR-20a, -28-3p & COPD diagnosis & Serum & Downregulated & & $(136)$ \\
\hline Profile of 9 miRNAs & $\begin{array}{l}\text { Environmental factors in } \\
\text { COPD subjects }\end{array}$ & & Differentially expressed & & $(137)$ \\
\hline miR-1 & Atrophy & Serum / limb tissue & $\begin{array}{l}\text { Downregulated / } \\
\text { Upregulated }\end{array}$ & $\begin{array}{l}\text { pAKT, HDAC3, HDAC4, IGF-1, } \\
\text { SIRT-1 }\end{array}$ & $(133,138)$ \\
\hline miR-7 & $\begin{array}{l}\text { COPD diagnosis, } \\
\text { inflammation }\end{array}$ & Serum, ASMCs & Upregulated & Epac1 & $(136,139)$ \\
\hline $\operatorname{miR}-100(-5 p)$ & COPD severity & Serum, leukocytes & $\begin{array}{l}\text { Downregulated/ } \\
\text { upregulated }\end{array}$ & $\begin{array}{l}\text { Autophagy, TLR, NSCLC, } \\
\text { cardiomyopathy }\end{array}$ & $(88,136)$ \\
\hline miR-34 (a, b, c, c-5p) & $\begin{array}{l}\text { Lung function, apoptosis, } \\
\text { emphysema }\end{array}$ & $\begin{array}{l}\text { Serum, lung tissue, pmvECs, } \\
\text { BECs, sputum }\end{array}$ & $\begin{array}{l}\text { Downregulated/ } \\
\text { upregulated }\end{array}$ & $\begin{array}{l}\text { HIF-1 } \alpha, \text { Notch-1R, SIRT-1 and } 6 \text {, } \\
\text { SERPINE1 }\end{array}$ & $\begin{array}{c}(81,125,136 \\
140-142)\end{array}$ \\
\hline miR-181a, c & $\begin{array}{l}\text { COPD development, } \\
\text { inflammation, ROS }\end{array}$ & Serum, lung tissue, BECs & Downregulated & $\begin{array}{l}\text { MMP, cell growth, apoptosis, NKs, } \\
\text { CCN1 }\end{array}$ & $(118,143)$ \\
\hline miR320a, b,d & $\begin{array}{l}\text { CRD differentiation, lung } \\
\text { function, inflammation }\end{array}$ & Serum, PBMCs, BECs & Upregulated & $\begin{array}{l}\text { T-cellR, FOXO, TGF- } \beta, \text { MAPK, } \\
\text { PISK-AKT, IL1B }\end{array}$ & $(130,144,145)$ \\
\hline miR-30a-3p & $\begin{array}{l}\text { Correlate with pulmonary } \\
\text { function (FEV1) }\end{array}$ & Sputum & Downregulated & & (81) \\
\hline $\operatorname{miR}-145$ & $\begin{array}{l}\text { Differentiating CRDs, } \\
\text { fibrosis and immunity }\end{array}$ & $\begin{array}{l}\text { Sputum, serum, ASMCs, } \\
\text { BECs, lung tissue, plasma }\end{array}$ & $\begin{array}{l}\text { Upregulated/ } \\
\text { downregulated }\end{array}$ & SMAD3, KLF4 CFTR, KLF5 & $\begin{array}{c}(70,111,131 \\
146-148)\end{array}$ \\
\hline miR-338/(-3p) & $\begin{array}{l}\text { Differentiation of asthma, } \\
\text { COPD and ACO }\end{array}$ & Sputum, serum, plasma & $\begin{array}{l}\text { Upregulated/ } \\
\text { downregulated }\end{array}$ & $R A B 14$, IGF2R & $(70,131)$ \\
\hline miR-27a & $\begin{array}{l}\text { Associated to muscle } \\
\text { weakness and atrophy }\end{array}$ & $\begin{array}{l}\text { Vastus lateralis from limb } \\
\text { tissue }\end{array}$ & Upregulated & HDAC3, HDAC4, IGF-1 and SIRT-1 & $(133)$ \\
\hline
\end{tabular}

lung myofibroblasts, while also negatively regulating cytokine expression of airway smooth muscle cells (ASMCs) $(146,147)$. Mucus hypersecretion, is in turn regulated by several miRNAs in bronchial biopsies by targeting the mucin-related genes (90) (Table 2). Other miRNAs, such as miR-101 and miR-144, are upregulated in COPD lungs activating the ERK pathway (120, 151), while miR-15b is also increased in COPD lungs, and the expression of its target SMAD7 is decreased (79).

MiRNAs are also important in COPD comorbidities like limb-muscle weakness, as it has been shown that miR-1, miR206, and miR-27a are upregulated in limb tissues from weak muscle COPD (133). Decreased levels of miR-637 in COPD pulmonary artery smooth muscle cells (PASMCs) are related to pulmonary hypertension (84), while miR-197 is involved in ASMCs proliferation and phenotype (85), and miR-183 expression is augmented in blood from COPD and related to disease severity, targeting KCNMB1 in lungs and smooth muscle cells (99).
Some miRNAs have been associated with emphysema, another COPD hallmark, like miR-638 (103); or miR-223 (110). On the contrary, others present protective effects on emphysema, like miR-452, appearing downregulated in alveolar macrophages from COPD (82), or miR-34c, that is also downregulated in moderate compared to mild emphysematous tissue (140).

\section{Cigarette Smoke Induces Tissue miRNA Changes Associated With Malignancy}

As previously said, miRNAs are profoundly implicated in the regulation of pathogenesis of respiratory diseases such as asthma and COPD. To begin with, miRNAs are affected by cigarette smoke exposure. Many researchers have studied the effect of cigarette smoke extract (CSE), both in vivo and in vitro, showing modulations in miRNA expression that are accompanied by the consequent functional effect.

In COPD, control of the inflammation induced by cigarette smoke is critical and is performed by miRNAs like miR-135b or 
miR-29b, that regulates $I L 1 R 1, I L 1 \beta$, and IL-8, respectively (128, 152). Indeed, in lung tissue and blood from COPD individuals, several cytokines such as IL- 6 or TNF- $\alpha$ are found downregulated by the action of miR-203 (153). MiR-146a plays an important role in COPD as previously commented. It is upregulated in response to cigarette smoke and fine-tunes the immune response by controlling cyclooxygenase-2 (COX-2) expression in fibroblasts (91). MiR-146a is also upregulated in epithelial cells in response to particulate matter and acts as a negative feedback loop that involves IL-6 and IL-8 (NF- $\kappa \beta$ signaling) (92). Nevertheless, the function of this miRNA might be more complex, as another study showed that fibroblasts from COPD stimulated with IL- $1 \beta$ and TNF- $\alpha$ produce less miR-146a, resulting in a high prostaglandin $\mathrm{E}_{2}$ $\left(\mathrm{PGE}_{2}\right)$ expression (89). This can be supported by data that show that the minor allele of the rs2910164 polymorphism associates

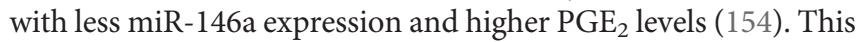
complexity might be explained by how this miRNA is expressed in a cell-specific manner as it seems to be downregulated in COPD sputum but overexpressed in lung tissue $(79,81)$.

This is not the only association of miRNA polymorphisms in COPD. Some polymorphisms provide resistance, as in rs3746444 (miR-499) and rs11614913 (miR-196a2), both associated with COPD protection, bronchodilator response and, to a lesser extent, COX-2 expression (miR-146 single nucleotide polymorphisms) (154-157).

Another study showed that miR-218-5p is reduced in lung tissue from COPD and healthy smokers and in mice and 16HBE exposed to CSE, and its expression correlates directly with $\mathrm{FEV}_{1}$ values. This miRNA performs a protective role by reducing the inflammation in COPD lungs $(122,123)$, something that has been corroborated by other studies (101, 122-124). Similarly, miR-181c targets CCN1 and reduces inflammation, reactive oxygen species (ROS), and neutrophil infiltration (143). MiR483-5p is able to reduce Beas-2B proliferation and alpha-smooth muscle actin ( $\alpha$-SMA) and fibronectin production in fibroblasts (158) just like let-7c, which is decreased in COPD sputum and lungs from mice and rats exposed to $\operatorname{CSE}(78,81,159)$.

Other miRNAs exert similar effects, like miR-145-5p, which is able to reduce TNF- $\alpha$, IL-8, and IL-6 (111). Nevertheless, the role of this miRNA is not clear, existing contradictory data about it (148).

In blood samples from smoking COPD patients, miR-149-3p was downregulated, and monocytes exposed to CSE diminished this miRNA expression and upregulated TLR4 and $N F-\kappa \beta$, which increases inflammation (160). This is also observed for miR3202, which suppresses the increase of TNF- $\alpha$ and interferon gamma (IFN- $\gamma$ ) induced by CSE in lymphocytes (161), and similarly for miR-150, who has a comparable role (109).

The methylation effect induced by CSE was observed in miRNAs from human bronchial epithelial cells (HBECs), where miR-218 and let-7c inhibition is related to HBE malignancy (112, 121, 162). MiRNAs are regulated by epigenetics, but they also regulate the epigenetic landscape, like miR-217. This miRNA is downregulated by CSE and, at the same time, CSE upregulates the long-noncoding RNA (lncRNA) MALAT1, which is a target of miR-217 inducing malignancy (163).
Some miRNAs are upregulated directly by CSE, like miR-21, which is induced by hypoxia-inducible factor 1-alpha (HIF-1 $\alpha$ ) $(114,164)$, or others, like miR-664a-3p (targets FHL1), which is raised in lung tissue and peripheral blood mononuclear cells (PBMCs) from COPD patients, and in Beas-2B cells exposed to CSE (165). Exosomes are also carriers for pathogenic miRNAs, as CSE-treated HBECs produce exosomes carrying miR-21, inducing myofibroblast differentiation and increasing $\alpha$-SMA and collagen-I through HIF- $1 \alpha$. Interestingly, downregulation of miR-21 in mice prevented remodeling by CSE (113). This miRNA is also implicated in the autophagy and apoptosis produced by CSE in lung tissues of both mice and $16 \mathrm{HBE}$ cells, being associated with worse lung function, proving its potential as therapeutic target in $\operatorname{COPD}(115,116)$.

It is known that CSE upregulates miR-34a expression in human pulmonary microvascular endothelial cells and increases their apoptosis by targeting NOTCH1 receptor (141), although this relation seems to be the inverse in serum from women with COPD exposed to biomass smoke (117). MiR-34a upregulation is also induced by oxidative stress (related to CSE) via phosphatidylinositol 3-kinase (PI3K) signaling in HBECs, which downregulates the antiaging-related deacetylases SIRT1 and SIRT6 (166), being this result confirmed in another study (142).

In the same way, CSE upregulates miR-206 in human pulmonary microvascular endothelial cells and in COPD patients, inducing cell apoptosis (134). CSE exposure, in both mice and Beas-2B cells, increased miR-130a levels, inducing a decrease in WNT1 and therefore causing cell injury, proliferation, and migration by regulation of $\mathrm{Wnt} / \beta$-catenin signaling (167). Similarly, CSE upregulates miR-195 in Beas-2B cells, increasing phospho-AKT and IL-6 synthesis (96). To the contrary, other miRNAs, such as the anti-malignant miR-200c, are indirectly downregulated by CSE and IL- 6 through NF- $\kappa \beta$ signaling (168).

CSE exposure releases circulating endothelial microparticles that are miRNA-enriched and, when engulfed by macrophages, can inhibit their efferocytosis activity (102). Moreover, expression of HIF- $1 \alpha$ is controlled by miR-34a and miR-199a$5 \mathrm{p}$, both overexpressed in COPD lungs, and also by miR-186 in fibroblasts, showing the intricacy of miRNA regulation (125, 169). Confirming this complex interplay of miRNA master regulation, miR-199a-5p is downregulated in regulatory $\mathrm{T}$ cells from COPD. This miRNA targets the TGF- $\beta$ pathway, and its aberrant expression may implicate adaptive immunity dysregulation (126). MiR-199a-5p downregulation is also present in monocytes from COPD patients, where the protein unfolding response is activated and involved in COPD pathology (170), while it also seems to regulate pulmonary artery hypertension through targeting of SMAD3 (127). This account for the very different functions that miRNAs may perform depending on which tissues or cells are present, and how their expression is influenced by the pathological environments, performing a very specifically fine tuning of gene expressing that occurs in a systemic manner.

Monocytes exposed to CSE also upregulate miR-132 expression inducing an increase in epidermal growth factor 
receptor, IL-1 $1 \beta$, and TNF- $\alpha$. Similar results were observed in $16 \mathrm{HBE}$ cells, and indeed this miRNA is upregulated in serum from COPD and smokers (97). In addition, ASMCs have deregulated miRNA expression due to the CSE effect, as seen by the upregulation of miR-7 and the consecutive reduction of its anti-inflammatory target Epac1 in ASMCs and COPD lungs $(139,171)$. Likewise, fibroblast behavior and function are altered by miRNAs modulated by CSE, adding another layer to the system regulation of miRNAs function in pathological status (93, 106, 107, 135, 172).

Finally, in vitro and in vivo CSE models showed that the increased DNA damage response due to CSE is also regulated by miR-126, whose downregulation in COPD causes ATM protein kinase activation promoting tissue dysfunction and aging (104).

\section{Differential Expression of miRNAs in Asthma and COPD and Their Roles as Disease Mediators and Biomarkers}

The implications of miRNAs in the human asthmatic response have been widely investigated in both pediatric and adult populations. In 2012, a study by Liu et al. showed differences in the miRNA profile between asthmatic children and healthy controls (63). They performed a miRNA microarray to screen for differential expression of miRNAs in the pediatric population and found upregulation of miR-221 and miR-485-3p in asthmatic children. Also, the authors identified a potential target of both miRNAs, SPRED2, a negative regulator of different mechanisms in asthma such as airway inflammation and hyperresponsiveness, by modulating IL-5 signaling pathway. These results were confirmed in a murine model of asthma, showing a significant reduction of Spred-2 in asthmatic mice. In the same context, miR-3162-3p was identified as upregulated in childhood asthma implicated in remodeling through $\beta$-catenin (64). Wang et al., in 2015, observed an altered miRNAs signature in peripheral blood from patients with childhood asthma, showing that the levels of plasma miR-let-7c, miR-486, and miR-1260a in children with asthma were significantly higher than in healthy individuals (173).

To ascertain how miRNAs are involved in adult response to asthma, several studies in adulthood population have also been performed. Most research compares the miRNAs profile between asthmatics and controls in a variety of sample types. Other studies on miRNAs in asthma in adult population have been reported, describing a number of miRNAs such as miR-20b, miR-138, miR143, miR-145, and others and their role in adulthood asthma (174).

Examples of miRNA profiles that allow COPD diagnosis, development or differentiation against healthy conditions have been shown in serum $(118,136)$. Also, a set of nine miRNAs were found to be differentially expressed in serum between healthy, COPD, and a migrant population with COPD, showing that miRNAs may change with exposure to different environmental factors (137).

Plasma levels of miR-106b are associated with COPD patients versus normal smokers (86), and levels of seven miRNAs are distinctive COPD biomarkers distinguishing from healthy subjects and asthma patients, with miR-145-5p being related to severity and miR-338-3p related to smoking COPD (131). Also, in exhaled breath condensate has been described miRNA profiles that are differential between COPD, healthy patients, and asthmatics (100). Discriminating between COPD and similar diseases has also implemented miRNA studies. Blood cell miRNAs (a profile of 14 miRNAs) and clustered miRNAs from BALF can be used as biomarkers for discrimination of COPD against lung cancer $(87,175)$. Moreover, in blood, nine miRNAs including members of the miR-320 family, which target mitogenactivated protein kinase (MAPK) pathways, can be used for lungcancer prediction in COPD subjects (98). Finally, the combined expression of hsa-miR-195 and hsa-miR-143, obtained from databases, is able to identify lung cancer compared to diseasefree status, but cannot distinguish COPD from lung cancer (176). From peripheral leucocytes, differential expression of miR-106b$5 p$, miR-183-5p, miR-125a-5p, and miR-100-5p was found in COPD compared to healthy controls, and miR-106b-5p was directly correlated with disease severity alleviation (88). Several studies have focused their interest on miRNAs from specific immune system cells exploring the implication of these structures in processes linked to asthma or COPD. For example, miR-24 and miR-27 have implications for the type 2 response by regulating IL-4 production by T-cells (61). Other miRNAs such as miR-17 and miR-19 have regulatory functions on $\mathrm{T}$ cell proliferation and differentiation to Th1, Th17, and regulatory $\mathrm{T}$ cells or by modulating type 2 immune response by inducing PI3K, JAK-STAT, and NF- $\kappa \beta$ signaling pathways (177). One of the most widely studied is miR-21. The first study that demonstrated the implication of miR-21 in allergic airway inflammation is by $\mathrm{Lu}$ et al. (66). The authors observed an upregulation of miR-21 in transgenic mice with allergic inflammation compared to controls. Through predictive algorithms, they identified potential target genes such as $I L$ $12 p 35$. This gene is implicated in type 1 immune response; thus, high levels of miR-21 repress the expression of $I L-12 p 35$, contributing to type 2 polarization characteristic of asthma and other allergic diseases. In another experimental in vivo model of asthma published in 2011, Lu et al. observed the preventive role of miR-21 in the expression of IL-3, IL-5, and IL-12 (178). In their study, the group observed that this miRNA may play a role as regulator in type 1/type 2 immune response balance, repressing cytokines of both types of response. In the same way, other miRNAs have been associated with asthma response in murine models, including miR-1, miR-145, miR-150, and miR-155 (179). Also, the let-7 family comprises the most abundant miRNAs in mouse lungs, playing a potent proinflammatory role in asthma (60). In particular, let-7a is an essential regulator of IL-13, which is a key cytokine that induces airway hyperresponsiveness in the lung tissue of asthmatics. Repression of this cytokine can alleviate allergic asthma symptoms. However, mmu-let-7a is markedly suppressed in Th2 cells, allowing IL-13 expression and stimulating the typical type 2 response of asthma pathology.

T lymphocytes are crucial in asthma pathogenesis, specifically orchestrating type 2 immune response. Naïve T cells turn into 
Th2 cells, releasing a set of cytokines (IL-4, IL-5, and IL-13), which triggers the characteristic processes of asthma (180). In this case, miRNAs related to $\mathrm{T}$ cells play an important role in type 2 immune response and asthma pathology. One of these miRNAs is miR-29b, which is involved in the development of asthma. This miRNA indirectly affects to Th2 response by regulating T-box transcription factors and IFN- $\gamma$ production in $\mathrm{T}$ helper cells (181), so a lower expression of this miRNA in asthmatic lung allows a higher production of IFN- $\gamma$ in order to recover Th1/Th2 balance in asthmatic lungs (182). According to miR-19a, Simpson et al. in 2014 showed that this miRNA is expressed by $\mathrm{T}$ cells and promotes Th2 cytokine production by simultaneously targeting inhibitors of the NF- $\kappa \mathrm{B}$, JAK-STAT, and PI3K pathways (177). Also, they observed that miR-19a had higher expression in human airway-infiltrating $\mathrm{T}$ cells in asthma. MiR-19a promotes cytokine production, amplifying inflammatory signaling by inhibiting PTEN, the signaling inhibitor SOCS1, and the deubiquitinase A20. Another important miRNA linked to $\mathrm{T}$ cells is miR-34a. This miRNA has been found to be upregulated in lungs of ovalbumin-induced asthmatic mice (183), modulating FOXP3, a master regulator of regulatory $\mathrm{T}$ cells.

Macrophages are immune cells involved in a wide range of functions related to innate and adaptive response, including maintenance of tissues and homeostasis. An imbalance between macrophages M1 (classically activated) and M2 (alternatively activated) phenotypes exists, and M2 polarization has been associated with development of asthma (184). Macrophages play a dual role in this disease, contributing to the induction and progression of eosinophilic lung inflammation and airway remodeling, and protecting against both development of neutrophilic inflammation and more severe airway hyperresponsiveness (185). This phenotype is induced by Th2 cytokines (IL-4 and IL-13), upregulating several genes. The role played by several miRNAs in macrophage polarization and their influence in asthma have been established (186). Several studies have demonstrated that miR-146a, miR-146b, and miR-21 promote macrophage polarization toward the M2 phenotype or suppress M1 polarization $(52,53)$. According to previous research, these miRNAs are upregulated in asthma (54). They act by joining target genes (NOTCH1, IRF5, and CSF1R), inhibiting the inflammatory response $(67,187,188)$. In macrophages from COPD patients, miR-344b-1-3p was upregulated and controlled TLR2, TNF, and IL1 $\beta$ expression (83).

In order to analyze the effects of miRNAs on mechanism associated to these pathologies, structural lung cells, including ASMCs and airway epithelial cells, are implicated in the pathologic mechanisms of asthma, and their miRNA content have been studied. On the one hand, ASMCs play a critical role in asthma pathogenesis due to their abilities related to hypercontractility, proliferation, and secretion of inflammatory mediators. Dileepan and collaborators showed that miR-708 and miR-140-3p regulate the MAPK and PI3K signaling pathways associated to asthma immune response in human ASMCs (46, 51, 189). Later, the same group showed that miR-708 and miR$140-3 p$ exert different effects in other proinflammatory genes, including CCL2, CCL5, CCL11, CXCL8, CXCL10, and CXCL12 (47). Moreover, other miRNAs from ASMCs have been described, such as miR-145, miR-146a-5p, and miR-638, altering the functions of airway muscle cells (48-50).

On the other hand, airway epithelial cells are another cell type implicated in several processes of asthmatic pathogenesis, including airway remodeling, epithelial barrier repair, and production of several proinflammatory mediators (190). In this context, a number of miRNAs have been described in this cell type, regulating their functions or other pathological processes of asthma. In 2018, Zhang et al. investigated the role of miR-221 in airway epithelial cell injury in asthma (65). This miRNA was significantly increased in bronchial epithelial cells from asthmatic subjects compared to healthy controls and was implicated in epithelial cell injury in asthma by inhibiting SIRT1 expression. However, there are several miRNAs that mitigate inflammatory status. Lambert and co-workers showed that miR-146a is released by airway epithelial cells in response to inflammatory stimuli like TNF- $\alpha$ (55). This fact constitutes an anti-inflammatory mechanism to enhance glucocorticoid effects. In addition, this miRNA, in conjunction with miR-146b, has been described as a negative regulator of inflammatory gene expression (PTGS2 and IL1B) in lung epithelial and smooth muscle cells (56).

Other studies set out to find miRNAs that can be used to predict comorbidities; for instance, in blood, miR-210 expression can differentiate subjects with COPD and ischemic stroke from those with COPD or ischemia alone (191). MiR-1 reduction has been related to quadriceps skeletal muscle dystrophy in COPD (138). Plasma miRNAs can be used to identify patients with acute exacerbations of COPD such as miR-125b (105). PBMCderived miRNAs are also differentially expressed in acute exacerbations of COPD compared to stable COPD and can differentiate between both conditions (129).

As previously described, plasma and exhaled breath condensate present differential miRNA profiles between asthma and COPD, which may be used to differentiate these diseases $(100,131)$. Nevertheless, having one of these respiratory diseases does not protect an individual against the other, so they may be present concomitantly. Asthma-COPD overlapping (ACO) is a condition where subjects present characteristics of both COPD and asthma, and it has been described in the Global Initiative for Chronic Obstructive Lung Disease-ACO guidelines (192). These subjects are normally defined as COPD subjects with eosinophilia (blood eosinophil count $\geq 200$ eosinophils $/ \mu \mathrm{L}$ ) or asthmatics with chronic airway obstruction and smoking habit ( $\geq 20$ pack per year) (193). Some miRNAs have been described as differentially expressed for ACO and can distinguish between asthma, COPD, and ACO. MiR-619-5p is downregulated in eosinophilic COPD subject serum compared to smoking and non-smoking asthmatics and COPD, and miR4486 is differentially expressed in eosinophilic COPD when compared to non-smoking asthmatics, showing that even within the ACO group differences in miRNA expression can be found. The targets of this set of miRNAs include epidermal growth factors belonging to the ErbB signaling pathway 
associated to pathogenic inception of lung diseases and to the metabolism of xenobiotics by cytochrome P450 signaling pathways involved in ROS (194). Finally, our research group has showed that combined expression of miR-185-5p, miR-320a, and miR-21-5p was able to differentiate asthmatics from COPD and ACO with high sensitivity and specificity. Like in the previous article these deregulated miRNAs in asthma are able to regulated genes belonging to Erb2, MAPK, AMPK, and PI3K/ AKT pathways that control cell proliferation and muscle contraction, alongside other targeted pathways as T-cell receptor, FoxO or TGF- $\beta$ which are key in immune regulation. The regulation of those pathways by asthma specific miRNAs may account for the differences in asthma pathology compared to those other respiratory diseases (145).

In sputum, expression of miR-338 is higher in subjects with respiratory diseases (asthma, COPD, and ACO) compared to healthy subjects; similarly, miR-338 is higher in asthma than in COPD. The study by Lacedonia et al. also showed that miR-145 is increased in sputum supernatant of COPD and asthmatics versus controls, and that serum miR-338 levels are lower in ACO and COPD compared to healthy controls (70). Finally, miR$146 a-5 p, m i R-10 a-5 p$, and miR-31-5p have been shown to play a common role in both CRDs $(94,108)$.

Together, these works have demonstrated a variety of miRNAs dysregulated in asthma and COPD in relation to healthy subjects and promising results have been found, including the use of miRNAs as biomarkers. However, this is a broad field of research and many of the specific mechanisms and particular means of miRNA regulation in these respiratory diseases remain to be discovered, and systems biology can help to solve this enigma.

\section{MiRNAs AND TREATMENTS IN LUNG DISEASES}

\section{MiRNAs and Asthma Treatment}

Glucocorticoids (GCs) remain the cornerstone of therapy for treating the inflammatory component of asthma and preventing asthma exacerbations. However, clinical response to GCs is complex and varies among individuals, as well as within the same individual, and some patients are resistant to this therapy. Different factors belonging to microenvironment can alter the canonical GC-induced signaling pathways, leading to reduced efficacy, collectively termed as sub-sensitivity, which include the entire spectrum of steroid-insensitivity and -resistance (195). Steroid sensitivity has been associated with different mechanisms, including dysregulated expression of GC receptor isoforms, neutrophilic inflammation and TH17 cytokines, oxidative stressinduced factors, and the downstream effect on histone deacetylase (HDAC) activation and gene expression. Recently, a new factor has been added in order to explain this phenomenon: the alterations in the expression of key transcription elements like miRNAs. Several studies conducted in this area, suggesting that circulating miRNAs may be useful potential biomarkers of asthma status or response to therapy (179).
In this sense, miR-155 has been the focus of different studies. Zhou et al. proposed that GCs may affect the inflammatory response by suppressing miR-155; these authors found that GCs attenuate lipopolysaccharide-induced inflammation and sepsis via downregulation of miR-155 expression (196), and forced miR-155 expression reverts the anti-inflammatory role of GCs (197, 198). In addition, miR-155-5p and miR-532-5p were identified as significantly associated with changes in dexamethasone-induced transrepression of NF- $\kappa \beta$. Authors identified these two functional circulating miRNAs predictive of asthma ICS treatment response over time, with an AUC of 0.86 (199).

Another miRNA that has been widely studied is miR-21. The study of Hammad et al. revealed a negative association between miR-21 and $\mathrm{FEV}_{1}$ post ICS treatment, which highlights the role in ICS treatment outcome as $\mathrm{FEV}_{1}$ reflects the grade of airway obstruction after ICS treatment (95). Elbehidy et al. found that miR-21 could be a novel predictor of ICS response, which helps in decision-making and identifying patients who are likely or unlikely to benefit from ICS therapy reducing the risk of side effects and sparing patients from the disappointment of treatment failure. MiR-21 had a predictive value in differentiating steroid-sensitive from steroid-resistant patients with an AUC value of 0.99 (200). Similar results were described by $\mathrm{Wu}$ et al. in 2014, who found that miR-21 expression was up-regulated in asthmatic adult bronchial epithelial cells regardless of treatment (201), but expression levels were decreased following ICS therapy (202).

Also, Kim et al. found that miR-21 drives severe, steroidinsensitive experimental asthma by amplifying PI3K-mediated suppression of HDAC2; thus, inhibition of increased miR-21 or $\mathrm{PI} 3 \mathrm{~K}$ responses suppresses disease and restores steroidsensitivity (119).

Other studies investigating the expression profiles of 579 miRNAs in transgenic mice revealed that miRNAs were differentially expressed upon induction of experimental asthma following treatment with doxycycline and additionally suggested that miR-21 was the most up-regulated miRNA $(66,203)$.

Other authors reported an increase in infection-induced miR9 in the airways of a mouse model and a similar increase in miR9 in the sputum of neutrophilic asthmatics. These researchers therefore propose that miR-9 regulates glucocorticoid receptor signaling and steroid-resistance by reducing protein phosphatase 2A activity. Thus, blocking miR-9 function restores steroid sensitivity and suggests that this might serve as a novel approach for the treatment of steroid-resistant AHR (204).

One of the most important challenges may be to find biomarkers predicting treatment outcomes, and for this reason McGeachie et al. in 2017 investigated serum expression of 738 miRNAs in 160 children with asthma aged 5-12 years in search of predictors of asthma remission at the age of 14 . The model, which was based on 12 variables including different miRNAs (miR-146b-5p, miR-106a, miR-126, and miR-30a), allowed prediction of remission with a sensitivity of $84 \%$ and a specificity of $70 \%$. Thus, they hypothesize that miRNAs are potentially predictive biomarkers for treatment outcome (205). 
However, not all authors agree on the role of miRNAs as regulators of GC treatment. Williams et al. sustain that changes in miRNA expression do not appear to be involved in the antiinflammatory action of the corticosteroid budesonide (206). This discrepancy may be explained by the fact that the inflammatory changes were too mild, and by the degree of cellular heterogeneity in airway biopsies.

\section{MiRNAs and COPD Treatment}

The main goal of pharmacologic COPD therapy is to treat the symptoms, reduce the frequency and severity of exacerbations, and improve tolerance and health status (207).

The main types of drugs normally used to treat COPD include long-acting $\beta_{2}$-agonists, long-acting muscarinic antagonists, and ICS, which are the most widely used treatment as antiinflammatory agents in COPD. However, a high percentage of COPD patients show a poor response to this therapy (208). It has now been recognized that current COPD treatments such as corticosteroids work, in part, through epigenetic mechanisms (209) and miRNAs is one of them (37).

In a recent manuscript authored by Faiz et al. (144) four miRNAs with changed expression after 6- and 30-month treatment with ICS compared with basal status (without any treatment) were identified. MiR-708 and miR-155 were downregulated and miR-320d and miR339-3p were upregulated in both periods of time after treatment (6 and 30 months). Moreover, three were also altered in the same direction by ICS plus long-acting $\beta 2$-agonists compared to placebo at 6 months of therapy: miR-320d, miR-339-3p, and miR-708; in vitro, these data were confirmed for miR-320d. Overexpression of miR$320 \mathrm{~d}$ significantly reduced the IL- $1 \beta$-induced activation of NF- $\mathrm{\kappa B}$ signaling compared to miRNA negative control. Thus, the negatively correlated predicted targets of miR-320d are diminished by ICS treatment. So, this study identified four miRNAs affected by shortand long-term treatment with ICS compared to placebo in patients with moderate to severe COPD (144) and miRNAs associated with ICS therapy and inflammation provide relevant candidates as potential therapeutic targets in chronic inflammatory diseases.

In addition, the increase of HDAC2 could reduce GC insensitivity in some patients. Leuenberger et al. (110) showed that HDAC2 is directly targeted by miR-223 by binding to seed matches located in the 3'UTR of this mRNA transcript; in addition, the activity of total HDAC and HDAC2 in pulmonary endothelial cells is repressed in response to miR-223 overexpression. The reduced activity of this histone has been classically described in COPD patients and a significant inverse correlation between HDAC2 and miR-223 level has been observed in this COPD population (110). Therefore, this miR-223, through regulation of another epigenetic factor as the HDAC2, could interfere with treatment efficacy in COPD disease.

As commented previously, miR-146a has been described as an enhancer of the anti-inflammatory effects of GCs (55) and is negatively correlated with inflammation and Global Initiative for Chronic Obstructive Lung Disease stage in both stable and acute exacerbation COPD patients (210). COPD patients show an increased secretion of $\mathrm{PGE}_{2}$, which results in collagen overproduction and finally reduces lung capacity. In this sense,
miR-146a expression is reduced in COPD patients and its target, COX-2, is simultaneously increased with a consequent increase of $\mathrm{PGE}_{2}$ levels (89). As COX-2 is sensitive to steroids and miR146a target, this miRNA could contribute to the antiinflammatory effect of this drug to reduce the increase of mucus and worsening of COPD evolution.

Moreover, as we have previously commented, COPD could have different etiologies such as tobacco or biomass smoke exposure. A recent manuscript from Velasco-Torres et al. on COPD due to biomass smoke exposure reported downregulation of miR-34a which implicates an activation of Notch 1 signaling. This finding is relevant because Notch 1 could represent an important target for therapy in these phenotypes of COPD (117).

Though the list is still small, several miRNAs have been modified by classical COPD treatments and, likewise, these miRNAs act over therapy targets and could contribute in different ways to treatment response in this respiratory pathology.

\section{CLINICAL ADVANCES IN THE USE OF MiRNAs}

Finally, miRNA-based treatment has emerged as a potential approach for clinical intervention in some respiratory diseases such as asthma and COPD. It is based on miRNAs delivery in the specific site of action which constitutes one of the main aspects of development in relation to miRNA like therapeutic approach. A long list of miRNAs has been found to be linked to initiation, progression, or exacerbations in both respiratory diseases, especially in COPD. However, some have been studied more in depth, showing a high potential as future therapeutic tools through their up- or downregulation. In this sense, miR-146a $(79,89), \operatorname{miR}-21$ (113, 116), miR-150 (109), miR-145-5p (131, 148), miR-320d (132, 144), miR-155 (62) miR-223 (211), or miR-3162-3p (212) seem to hold promise as future elements in the therapeutic repertoire for COPD and asthma, respectively, some of which are common for both pathologies such as miR146a (213-215) or miR-21 $(54,62)$.

All these examples show the never-ending list of miRNAs that, in the future, could potentially be a therapeutic approach in respiratory diseases. However, although the knowledge of miRNAs has grown exponentially in recent years, these data demonstrate that more studies are necessary before miRNAs can be employed as therapeutic tools. Currently, the idea of precision and personalized medicine is the objective for the near future, though this is a long and arduous path; thus, classical treatments continue to be the basis of therapy in asthma and COPD.

\section{CONCLUDING REMARKS}

This review summarizes the previous knowledge about miRNAs in chronic respiratory diseases as asthma and COPD, trying to be the first step forward for the compilation and application of systems biology approaches for understanding their roles. Many 
miRNAs present differential expression in diverse samples, and are known for their capability of being biomarkers or for having a specific role in the pathogenesis of these diseases, but the current approaches are unsuited for giving a systemic level view for data interpretation.

For overcoming this issue, systems biology may be the optimal tool. By the combination of data-driven model elaboration and model-driven experimental design, researchers might be able to elucidate how miRNAs work together in disease pathogenesis and diagnosis, giving the full picture view of miRNA regulatory system.

\section{AUTHOR CONTRIBUTIONS}

JC, JR-M, BS, MG-M, NR, and VP conceived of the review and wrote the manuscript. JC, JR-M, and VP prepared the figures. The review was performed under the supervision of JC and VP.

\section{REFERENCES}

1. Sahu I, Hebalkar R, Kar S, TS SV, Gutti U, Gutti RK. Systems biology approach to study the role of miRNA in promoter targeting during megakaryopoiesis. Exp Cell Res (2018) 366:192-8. doi: 10.1016/j.yexcr. 2018.03.022

2. Lee RC, Feinbaum RL, Ambros V. The C. elegans heterochronic gene lin-4 encodes small RNAs with antisense complementarity to lin-14. Cell (1993) 75:843-54. doi: 10.1016/0092-8674(93)90529-Y

3. Lai X, Eberhardt M, Schmitz U, Vera J. Systems biology-based investigation of cooperating microRNAs as monotherapy or adjuvant therapy in cancer. Nucleic Acids Res (2019) 47:7753-66. doi: 10.1093/nar/gkz638

4. Lai X, Bhattacharya A, Schmitz U, Kunz M, Vera J, Wolkenhauer O. A systems' biology approach to study microrna-mediated gene regulatory networks. BioMed Res Int (2013) 2013:703849. doi: 10.1155/2013/703849

5. Gomes CPC, Cho JH, Hood L, Franco OL, Pereira RW, Wang K. A review of computational tools in microRNA discovery. Front Genet (2013) 4:81:81. doi: 10.3389/fgene.2013.00081

6. Watanabe Y, Kanai A. Systems biology reveals microRNA-mediated gene regulation. Front Genet (2011) 2:29:29. doi: 10.3389/fgene.2011.00029

7. Breitling LP, Yang R, Korn B, Burwinkel B, Brenner H. Tobacco-smokingrelated differential DNA methylation: $27 \mathrm{~K}$ discovery and replication. Am J Hum Genet (2011) 88:450-7. doi: 10.1016/j.ajhg.2011.03.003

8. World Health Organization. Chronic Respiratory Diseases (2007). Available at: https://www.who.int/health-topics/chronic-respiratory-diseases\#tab= tab_1 (Accessed Accesed April 23, 2020).

9. Beasley R, Semprini A, Mitchell EA. Risk factors for asthma: Is prevention possible? Lancet (2015) 386:1075-85. doi: 10.1016/S0140-6736(15)00156-7

10. Salvi SS, Barnes PJ. Chronic obstructive pulmonary disease in non-smokers. Lancet (2009) 374:733-43. doi: 10.1016/S0140-6736(09)61303-9

11. Agusti A, Hogg JC. Update on the pathogenesis of chronic obstructive pulmonary disease. N Engl J Med (2019) 381:1248-56. doi: 10.1056/NEJMra1900475

12. Kudo M, Ishigatsubo Y, Aoki I. Pathology of asthma. Front Microbiol (2013) 4:263. doi: $10.3389 /$ fmicb.2013.00263

13. Macnee W. ABC of chronic obstructive pulmonary disease Pathology, pathogenesis, and pathophysiology. BMJ (2006) 332:1202-4. doi: 10.1136/ bmj.3327551.1202

14. Fahy JV. Type 2 inflammation in asthma-present in most, absent in many. Nat Rev Immunol (2015) 15:57-65. doi: 10.1038/nri3786

15. Holgate ST. Innate and adaptive immune responses in asthma. Nat Med (2012) 18:673-83. doi: 10.1038/nm.2731

16. Cañas JA, Sastre B, Rodrigo-Muñoz JM, del Pozo V. Exosomes: A new approach to asthma pathology. Clin Chim Acta (2019) 495:139-47. doi: $10.1016 /$ j.cca.2019.04.055
All authors contributed to the article and approved the submitted version.

\section{FUNDING}

This manuscript was supported by ISCIII - Instituto de Salud Carlos III, Fondo de Investigacioìn Sanitaria - FIS and FEDER (Fondo Europeo de Desarrollo Regional) [PI15/00803, PI18/00044 and FI16/ 00036], CIBERES, Merck Health Foundation funds and RTC-20176501-1 (Ministerio de Ciencia, Innovacioin y Universidades).

\section{ACKNOWLEDGMENTS}

The authors recognize Oliver Shaw, $\mathrm{PhD}$, English editor of IIS-FJD, for editing the manuscript for aspects of the English language.

17. Global Initiative for Asthma Management and Prevention 2020. Global Initiative for Asthma (2020). Available at: www.ginasthma.org (Accessed April 8, 2020).

18. Anderson GP. Endotyping asthma: new insights into key pathogenic mechanisms in a complex, heterogeneous disease. Lancet (2008) 372:1107-19. doi: 10.1016/S0140-6736(08)61452-X

19. Brown DW, Croft JB, Greenlund KJ, Giles WH. Average age at death from COPD in the United States: 1980-85, 1990-95, 2000-05. COPD J Chronic Obstr Pulm Dis (2009) 6:152-4. doi: 10.1080/15412550902918428

20. Smith MC, Wrobel JP. Epidemiology and clinical impact of major comorbidities in patients with COPD. Int J Chron Obstruct Pulmon Dis (2014) 9:871-88. doi: 10.2147/COPD.S49621

21. Barnes PJ, Shapiro SD, Pauwels RA. Chronic obstructive pulmonary disease: Molecular and cellular mechanisms. Eur Respir J (2003) 22:672-88. doi: 10.1183/09031936.03.00040703

22. Miravitlles M, Calle M, Soler-Cataluña JJ. Fenotipos clínicos de la EPOC. Identificación, definición e implicaciones para las guías de tratamiento. Arch Bronconeumol (2012) 48:86-98. doi: 10.1016/j.arbres.2011.10.007

23. Trupin L, Earnest G, San Pedro M, Balmes JR, Eisner MD, Yelin E, et al. The occupational burden of chronic obstructive pulmonary disease. Eur Respir J (2003) 22:462-69. doi: 10.1183/09031936.03.00094203

24. Taylor JD. COPD and the response of the lung to tobacco smoke exposure. Pulm Pharmacol Ther (2010) 23:376-83. doi: 10.1016/j.pupt.2010.04.003

25. Strzelak A, Ratajczak A, Adamiec A, Feleszko W. Tobacco smoke induces and alters immune responses in the lung triggering inflammation, allergy, asthma and other lung diseases: A mechanistic review. Int J Environ Res Public Health (2018) 15:1033. doi: 10.3390/ijerph15051033

26. Dewhurst JA, Lea S, Hardaker E, Dungwa JV, Ravi AK, Singh D. Characterisation of lung macrophage subpopulations in COPD patients and controls. Sci Rep (2017) 7:7143. doi: 10.1038/s41598-017-07101-2

27. Tsoumakidou M, Demedts IK, Brusselle GG, Jeffery PK. Dendritic cells in chronic obstructive pulmonary disease: New players in an old game. Am J Respir Crit Care Med (2008) 177:1180-6. doi: 10.1164/rccm.200711-1727PP

28. Quint JK, Wedzicha JA. The neutrophil in chronic obstructive pulmonary disease. J Allergy Clin Immunol (2007) 119:1065-71. doi: 10.1016/ j.jaci.2006.12.640

29. Eriksson-Ström J, Pourazar J, Linder R, Blomberg A, Lindberg A, Bucht A, et al. Cytotoxic lymphocytes in COPD airways: Increased NK cells associated with disease, iNKT and NKT-like cells with current smoking. Respir Res (2018) 19:244. doi: 10.1186/s12931-018-0940-7

30. Wang G, Xu Z, Wang R, Al-Hijji M, Salit J, Strulovici-Barel Y, et al. Genes associated with MUC5AC expression in small airway epithelium of human smokers and non-smokers. BMC Med Genomics (2012) 5:21. doi: 10.1186/ 1755-8794-5-21 
31. Gangl K, Reininger R, Bernhard D, Campana R, Pree I, Reisinger J, et al. Cigarette smoke facilitates allergen penetration across respiratory epithelium. Allergy Eur J Allergy Clin Immunol (2009) 64:398-405. doi: 10.1111/j.1398-9995.2008.01861.x

32. Krauss-Etschmann S, Meyer KF, Dehmel S, Hylkema MN. Inter-and transgenerational epigenetic inheritance: Evidence in asthma and COPD? Clin Epigenetics (2015) 7:53. doi: 10.1186/s13148-015-0085-1

33. Vucic EA, Chari R, Thu KL, Wilson IM, Cotton AM, Kennett JY, et al. DNA methylation is globally disrupted and associated with expression changes in chronic obstructive pulmonary disease small airways. Am J Respir Cell Mol Biol (2014) 50:912-22. doi: 10.1165/rcmb.2013-0304OC

34. Meek PM, Sood A, Petersen H, Belinsky SA, Tesfaigzi Y. Epigenetic Change (GATA-4 Gene Methylation) Is Associated With Health Status in Chronic Obstructive Pulmonary Disease. Biol Res Nurs (2015) 17:191-8. doi: $10.1177 / 1099800414538113$

35. Lee MK, Hong Y, Kim SY, Kim WJ, London SJ. Epigenome-wide association study of chronic obstructive pulmonary disease and lung function in Koreans. Epigenomics (2017) 9:971-84. doi: 10.2217/epi-2017-0002

36. Zhang Y, Yang R, Burwinkel B, Breitling LP, Holleczek B, Schöttker B, et al. F2RL3 Methylation in Blood DNA Is a Strong Predictor of Mortality. Int $J$ Epidemiol (2014) 43:1215-25. doi: 10.1093/ije/dyu006

37. Wu DD, Song J, Bartel S, Krauss-Etschmann S, Rots MG, Hylkema MN. The potential for targeted rewriting of epigenetic marks in COPD as a new therapeutic approach. Pharmacol Ther (2018) 182:1-14. doi: 10.1016/ j.pharmthera.2017.08.007

38. Song J, Cano-Rodriquez D, Winkle M, Gjaltema RAF, Goubert D, Jurkowski $\mathrm{TP}$, et al. Targeted epigenetic editing of SPDEF reduces mucus production in lung epithelial cells. Am J Physiol Lung Cell Mol Physiol (2017) 312:L334-47. doi: 10.1152/ajplung.00059.2016

39. Mehta A, Baltimore D. MicroRNAs as regulatory elements in immune system logic. Nat Rev Immunol (2016) 16:279-94. doi: 10.1038/nri.2016.40

40. Sittka A, Schmeck B. MicroRNAs in the Lung. Adv Exp Med Biol (2013) 774:121-34. doi: 10.1007/978-94-007-5590-1_7

41. Iorio MV, Piovan C, Croce CM. Interplay between microRNAs and the epigenetic machinery: An intricate network. Biochim Biophys Acta G (2010) 1799:694-701. doi: 10.1016/j.bbagrm.2010.05.005

42. Papadopoulos NG, Taka S, Tzani-Tzanopoulou P, Wanstall H. MicroRNAs in asthma and respiratory infections: Identifying common pathways. Allergy Asthma Immunol Res (2020) 12:4-23. doi: 10.4168/aair.2020.12.1.4

43. Rodrigo-Muñoz JM, Cañas JA, Sastre B, Rego N, Greif G, Rial M, et al. Asthma diagnosis using integrated analysis of eosinophil microRNAs. Allergy Eur J Allergy Clin Immunol (2019) 74:507-17. doi: 10.1111/all.13570

44. Wang J, Chen J, Sen S. MicroRNA as Biomarkers and Diagnostics. J Cell Physiol (2016) 231:25-30. doi: 10.1002/jcp.25056

45. Panganiban RP, Wang Y, Howrylak J, Chinchilli VM, Craig TJ, August A, et al. Circulating microRNAs as biomarkers in patients with allergic rhinitis and asthma. J Allergy Clin Immunol (2016) 137:1423-32. doi: 10.1016/ j.jaci.2016.01.029

46. Jude JA, Dileepan M, Subramanian S, Solway J, Panettieri RA Jr, Wasleth TF, et al. MiR-140-3p regulation of TNF- $\alpha$-induced CD38 expression in human airway smooth muscle cells. Am J Physiol Lung Cell Mol Physiol (2012) 303: L460-8. doi: 10.1152/ajplung.00041.2012

47. Dileepan M, Sarver AE, Rao SP, Panettieri RA, Subramanian S, Kannan MS. MicroRNA mediated chemokine responses in human airway smooth muscle cells. PloS One (2016) 11:e0150842. doi: 10.1371/journal.pone. 0150842

48. Liu Y, Sun X, Wu Y, Fang P, Shi H, Xu J, et al. Effects of miRNA-145 on airway smooth muscle cells function. Mol Cell Biochem (2015) 409:135-43. doi: 10.1007/s11010-015-2519-7

49. Faiz A, Weckmann M, Tasena H, Vermeulen CJ, Van Den Berge M, Ten Hacken NHT, et al. Profiling of healthy and asthmatic airway smooth muscle cells following interleukin-1 $\beta$ treatment: A novel role for CCL20 in chronic mucus hypersecretion. Eur Respir J (2018) 52:1800310. doi: 10.1183/ 13993003.00310-2018

50. Wang H, Yao H, Yi B, Kazama K, Liu Y, Deshpande D, et al. MicroRNA-638 inhibits human airway smooth muscle cell proliferation and migration through targeting cyclin D1 and NOR1. J Cell Physiol (2018) 234:369-81. doi: $10.1002 /$ jcp. 26930
51. Dileepan M, Jude JA, Rao SP, Walseth TF, Panettieri RA, Subramanian S, et al. MicroRNA-708 regulates CD38 expression through signaling pathways JNK MAP kinase and PTEN/AKT in human airway smooth muscle cells. Respir Res (2014) 15:107. doi: 10.1186/s12931-014-0107-0

52. Essandoh K, Li Y, Huo J, Fan GC. MiRNA-mediated macrophage polarization and its potential role in the regulation of inflammatory response. Shock (2016) 46:122-31. doi: 10.1097/SHK.0000000000000604

53. He X, Tang R, Sun Y, Wang YG, Zhen KY, Zhang DM, et al. MicroR-146 blocks the activation of M1 macrophage by targeting signal transducer and activator of transcription 1 in hepatic schistosomiasis. EBioMedicine (2016) 13:339-47. doi: 10.1016/j.ebiom.2016.10.024

54. Specjalski K, Niedoszytko M. MicroRNAs: future biomarkers and targets of therapy in asthma? Curr Opin Pulm Med (2020) 26:285-92. doi: 10.1097/ MCP.0000000000000673

55. Lambert KA, Roff AN, Panganiban RP, Douglas S, Ishmael FT. MicroRNA$146 \mathrm{a}$ is induced by inflammatory stimuli in airway epithelial cells and augments the anti-inflammatory effects of glucocorticoids. PloS One (2018) 13:e0205434. doi: 10.1371/journal.pone.0205434

56. Comer BS, Camoretti-Mercado B, Kogut PC, Halayko AJ, Solway J, Gerthoffer WT. MicroRNA-146a and microRNA-146b expression and anti-inflammatory function in human airway smooth muscle. Am J Physiol Lung Cell Mol Physiol (2014) 307:L727-34. doi: 10.1152/ ajplung.00174.2014

57. Levänen B, Bhakta NR, Torregrosa Paredes P, Barbeau R, Hiltbrunner S, Pollack JL, et al. Altered microRNA profiles in bronchoalveolar lavage fluid exosomes in asthmatic patients. J Allergy Clin Immunol (2013) 131:894-903. doi: 10.1016/j.jaci.2012.11.039

58. Zhao M, Li YP, Geng XR, Zhao M, Ma SB, Yang YH, et al. Expression Level of MiRNA-126 in Serum Exosomes of Allergic Asthma Patients and Lung Tissues of Asthmatic Mice. Curr Drug Metab (2019) 20:799-803. doi: 10.2174/1389200220666191011114452

59. Gon Y, Maruoka S, Inoue T, Kuroda K, Yamagishi K, Kozu Y, et al. Selective release of miRNAs via extracellular vesicles is associated with house-dust mite allergen-induced airway inflammation. Clin Exp Allergy (2017) 47:1586-98. doi: 10.1111/cea.13016

60. Polikepahad S, Knight JM, Naghavi AO, Oplt T, Creighton CJ, Shaw C, et al. Proinflammatory role for let-7 microRNAS in experimental asthma. J Biol Chem (2010) 285:30139-49. doi: 10.1074/jbc.M110.145698

61. Pua HH, Steiner DF, Patel S, Gonzalez JR, Ortiz-Carpena JF, Kageyama R, et al. MicroRNAs 24 and 27 Suppress Allergic Inflammation and Target a Network of Regulators of T Helper 2 Cell-Associated Cytokine Production. Immunity (2016) 44:821-32. doi: 10.1016/j.immuni.2016.01.003

62. ElKashef SMMAE, Ahmad SEA, Soliman YMA, Mostafa MS. Role of microRNA-21 and microRNA-155 as biomarkers for bronchial asthma. Innate Immun (2020) 1753425920901563:1-9. doi: 10.1177/1753425 920901563

63. Liu F, Qin HB, Xu B, Zhou H, Zhao DY. Profiling of miRNAs in pediatric asthma: Upregulation of miRNA-221 and miRNA-485-3p. Mol Med Rep (2012) 6:1178-82. doi: 10.3892/mmr.2012.1030

64. Fang C, Lu W, Li C, Peng X, Wang Y, Huang X, et al. MiR-3162-3p is a novel MicroRNA that exacerbates asthma by regulating $\beta$-catenin. PloS One (2016) 11:e0149257. doi: 10.1371/journal.pone.0149257

65. Zhang H, Sun Y, Rong W, Fan L, Cai Y, Qu Q, et al. miR-221 participates in the airway epithelial cells injury in asthma via targeting SIRT1. Exp Lung Res (2018) 44:272-9. doi: 10.1080/01902148.2018.1533051

66. Lu TX, Munitz A, Rothenberg ME. MicroRNA-21 Is Up-Regulated in Allergic Airway Inflammation and Regulates IL-12p35 Expression. J Immunol (2009) 182:4994-5002. doi: 10.4049/jimmunol.0803560

67. Caescu CI, Guo X, Tesfa L, Bhagat TD, Verma A, Zheng D, et al. Colony stimulating factor-1 receptor signaling networks inhibit mouse macrophage inflammatory responses by induction of microRNA-21. Blood (2015) 125: e1-13. doi: 10.1182/blood-2014-10-608000

68. Maes T, Cobos FA, Schleich F, Sorbello V, Henket M, De Preter K, et al. Asthma inflammatory phenotypes show differential microRNA expression in sputum. J Allergy Clin Immunol (2016) 137:1433-46. doi: 10.1016/ j.jaci.2016.02.018

69. Zhang K, Liang Y, Feng Y, Wu W, Zhang H, He J, et al. Decreased epithelial and sputum miR-221-3p associates with airway eosinophilic inflammation 
and CXCL17 expression in asthma. Am J Physiol Lung Cell Mol Physiol (2018) 315:L253-64. doi: 10.1152/ajplung.00567.2017

70. Lacedonia D, Palladino GP, Foschino-Barbaro MP, Scioscia G, Elisiana G, Carpagnano EG. Expression profiling of miRNA-145 and miRNA-338 in serum and sputum of patients with COPD, asthma, and asthma-COPD overlap syndrome phenotype. Int J Chron Obstruct Pulmon Dis (2017) 12:1811-7. doi: 10.2147/COPD.S130616

71. Suojalehto H, Lindström I, Majuri ML, Mitts C, Karjalainen J, Wolff H, et al. Altered microRNA expression of nasal mucosa in long-term asthma and allergic rhinitis. Int Arch Allergy Immunol (2014) 163:168-78. doi: 10.1159/ 000358486

72. Milger K, Götschke J, Krause L, Nathan P, Alessandrini F, Tufman A, et al. Identification of a plasma miRNA biomarker signature for allergic asthma: A translational approach. Allergy Eur J Allergy Clin Immunol (2017) 72:196271. doi: $10.1111 /$ all.13205

73. Baskara-Yhuellou I, Tost J. The impact of microRNAs on alterations of gene regulatory networks in allergic diseases. Adv Protein Chem Struct Biol (2020) 120:237-312. doi: 10.1016/bs.apcsb.2019.11.006

74. Nagano T, Katsurada M, Dokuni R, Hazama D, Kiriu T, Umezawa K, et al. Crucial Role of Extracellular Vesicles in Bronchial Asthma. Int J Mol Sci (2019) 20:2589. doi: 10.3390/ijms20102589

75. Fujita Y, Yoshioka Y, Ito S, Araya J, Kuwano K, Ochiya T. Intercellular communication by extracellular vesicles and their MicroRNAs in Asthma. Clin Ther (2014) 36:873-81. doi: 10.1016/j.clinthera.2014.05.006

76. Sastre B, Cañas JA, Rodrigo-Muñoz JM, del Pozo V. Novel modulators of asthma and allergy: Exosomes and microRNAs. Front Immunol (2017) 8:826. doi: $10.3389 /$ fimmu.2017.00826

77. Zhao M, Juanjuan L, Weijia F, Jing X, Qiuhua H, Hua Z, et al. Expression Levels of MicroRNA-125b in Serum Exosomes of Patients with Asthma of Different Severity and its Diagnostic Significance. Curr Drug Metab (2019) 20:781-4. doi: 10.2174/1389200220666191021100001

78. Izzotti A, Calin GA, Arrigo P, Steele VE, Croce CM, De Flora S. Downregulation of microRNA expression in the lungs of rats exposed to cigarette smoke. FASEB J (2009) 23:806-12. doi: 10.1096/fj.08-121384

79. Ezzie ME, Crawford M, Cho JH, Orellana R, Zhang S, Gelinas R, et al. Gene expression networks in COPD: microRNA and mRNA regulation. Thorax (2012) 67:122-31. doi: 10.1136/thoraxjnl-2011-200089

80. Kara M, Kirkil G, Kalemci S. Differential Expression of MicroRNAs in Chronic Obstructive Pulmonary Disease. Adv Clin Exp Med (2016) 25:21-6. doi: $10.17219 / \mathrm{ACEM} / 28343$

81. Van Pottelberge GR, Mestdagh P, Bracke KR, Thas O, Van Durme YMTA, Joos GF, et al. MicroRNA expression in induced sputum of smokers and patients with chronic obstructive pulmonary disease. Am J Respir Crit Care Med (2011) 183:898-906. doi: 10.1164/rccm.201002-0304OC

82. Graff JW, Powers LS, Dickson AM, Kim J, Reisetter AC, Hassan IH, et al. Cigarette Smoking Decreases Global MicroRNA Expression in Human Alveolar Macrophages. PloS One (2012) 7:e44066. doi: 10.1371/journal.pone.0044066

83. Xu H, Wu Y, Li L, Yuan W, Zhang D, Yan Q, et al. MiR-344b-1-3p targets TLR2 and negatively regulates TLR2 signaling pathway. Int J Chron Obstruct Pulmon Dis (2017) 12:627-38. doi: 10.2147/COPD.S120415

84. Sang HY, Jin YL, Zhang WQ, Chen LB. Downregulation of microRNA-637 increases risk of hypoxia-induced pulmonary hypertension by modulating expression of cyclin dependent kinase 6 (CDK6) in pulmonary smooth muscle cells. Med Sci Monit (2016) 22:4066-72. doi: 10.12659/MSM.897254

85. Musri MM, Coll-Bonfill N, Maron BA, Peinado VI, Wang RS, Altirriba J, et al. MicroRNA dysregulation in pulmonary arteries from chronic obstructive pulmonary disease: Relationships with vascular remodeling. Am J Respir Cell Mol Biol (2018) 59:490-9. doi: 10.1165/rcmb.2017-0040OC

86. Soeda S, Ohyashiki JH, Ohtsuki K, Umezu T, Setoguchi Y, Ohyashiki K. Clinical relevance of plasma miR-106b levels in patients with chronic obstructive pulmonary disease. Int J Mol Med (2013) 31:533-9. doi: 10.3892/ijmm.2013.1251

87. Molina-Pinelo S, Pastor MD, Suarez R, Romero-Romero B, González De La Peña M, Salinas A, et al. MicroRNA clusters: Dysregulation in lung adenocarcinoma and COPD. Eur Respir J (2014) 43:1740-9. doi: 10.1183/09031936.00091513

88. Wang R, Xu J, Liu H, Zhao Z. Peripheral leukocyte microRNAs as novel biomarkers for COPD. Int J Chron Obstruct Pulmon Dis (2017) 12:1101-12. doi: $10.2147 / C O P D . S 130416$
89. Sato T, Liu X, Nelson A, Nakanishi M, Kanaji N, Wang X, et al. Reduced miR-146a increases prostaglandin E2 in chronic obstructive pulmonary disease fibroblasts. Am J Respir Crit Care Med (2010) 182:1020-9. doi: 10.1164/rccm.201001-0055OC

90. Tasena H, Faiz A, Timens W, Noordhoek J, Hylkema MN, Gosens R, et al. MicroRNA-mRNA regulatory networks underlying chronic mucus hypersecretion in COPD. Eur Respir J (2018) 52:1701556. doi: 10.1183/ 13993003.01556-2017

91. Zago M, Rico de Souza A, Hecht E, Rousseau S, Hamid Q, Eidelman DH, et al. The NF- $\mathrm{KB}$ family member RelB regulates microRNA miR-146a to suppress cigarette smoke-induced COX-2 protein expression in lung fibroblasts. Toxicol Lett (2014) 226:107-16. doi: 10.1016/j.toxlet.2014.01.020

92. Liu L, Wan C, Zhang W, Guan L, Tian G, Zhang F, et al. MiR-146a regulates PM1-induced inflammation via NF- $\kappa$ B signaling pathway in BEAS-2B cells. Environ Toxicol (2018) 33:743-51. doi: 10.1002/tox.22561

93. Osei ET, Florez-Sampedro L, Tasena H, Faiz A, Noordhoek JA, Timens W, et al. miR-146a-5p plays an essential role in the aberrant epithelial-fibroblast cross-talk in COPD. Eur Respir J (2017) 49:1602538. doi: 10.1183/ 13993003.02538-2016

94. Tsai MJ, Tsai YC, Chang WA, Lin YS, Tsai PH, Sheu CC, et al. Deducting microRNA-mediated changes common in bronchial epithelial cells of asthma and chronic obstructive pulmonary disease-a next-generation sequencing-guided bioinformatic approach. Int J Mol Sci (2019) 20:553. doi: $10.3390 / \mathrm{ijms} 20030553$

95. Hammad Mahmoud Hammad R, Hamed DHED, Eldosoky MAER, Ahmad AAES, Osman HM, Abd Elgalil HM, et al. Plasma microRNA-21, microRNA-146a and IL-13 expression in asthmatic children. Innate Immun (2018) 24:171-9. doi: 10.1177/1753425918763521

96. Gu W, Yuan Y, Yang H, Wu H, Wang L, Tang Z, et al. Role of miR-195 in cigarette smoke-induced chronic obstructive pulmonary disease. Int Immunopharmacol (2018) 55:49-54. doi: 10.1016/j.intimp.2017.11.030

97. Diao X, Zhou J, Wang S, Ma X. Upregulation of miR-132 contributes to the pathophysiology of COPD via targeting SOCS5. Exp Mol Pathol (2018) 105:285-92. doi: 10.1016/j.yexmp.2018.10.002

98. Keller A, Fehlmann T, Ludwig N, Kahraman M, Laufer T, Backes C, et al. Genome-wide MicroRNA Expression Profiles in COPD: Early Predictors for Cancer Development. Genomics Proteomics Bioinformatics (2018) 16:16271. doi: 10.1016/j.gpb.2018.06.001

99. Cao Z, Zhang N, Lou T, Jin Y, Wu Y, Ye Z, et al. microRNA-183 downregulates the expression of $\mathrm{BKCa} 1$ protein that is related to the severity of chronic obstructive pulmonary disease. Hippokratia (2014) 18:328.

100. Pinkerton M, Chinchilli V, Banta E, Craig T, August A, Bascom R, et al. Differential expression of microRNAs in exhaled breath condensates of patients with asthma, patients with chronic obstructive pulmonary disease, and healthy adults. J Allergy Clin Immunol (2013) 132:217-9. doi: 10.1016/ j.jaci.2013.03.006

101. Schembri F, Sridhar S, Perdomo C, Gustafson AM, Zhang X, Ergun A, et al. MicroRNAs as modulators of smoking-induced gene expression changes in human airway epithelium. Proc Natl Acad Sci USA (2009) 106:2319-24. doi: $10.1073 /$ pnas.0806383106

102. Serban KA, Rezania S, Petrusca DN, Poirier C, Cao D, Justice MJ, et al. Structural and functional characterization of endothelial microparticles released by cigarette smoke. Sci Rep (2016) 6:31596. doi: 10.1038/srep31596

103. Christenson SA, Brandsma CA, Campbell JD, Knight DA, Pechkovsky DV, Hogg JC, et al. MiR-638 regulates gene expression networks associated with emphysematous lung destruction. Genome Med (2013) 5:114. doi: 10.1186/ gm519

104. Paschalaki KE, Zampetaki A, Baker JR, Birrell MA, Starke RD, Belvisi MG, et al. Downregulation of MicroRNA-126 Augments DNA Damage Response in Cigarette Smokers and Patients with Chronic Obstructive Pulmonary Disease. Am J Respir Crit Care Med (2018) 197:665-8. doi: 10.1164/ rccm.201706-1304LE

105. Hu HL, Nie ZQ, Lu Y, Yang X, Song C, Chen H, et al. Circulating miR-125b but not miR-125a correlates with acute exacerbations of chronic obstructive pulmonary disease and the expressions of inflammatory cytokines. Medicine (Baltimore) (2017) 96:e9059. doi: 10.1097/MD.0000000000009059

106. Ikari J, Nelson AJ, Obaid J, Giron-Martinez A, Ikari K, Makino F, et al. Reduced microRNA-503 expression augments lung fibroblast VEGF 
production in chronic obstructive pulmonary disease. PloS One (2017) 12: e0184039. doi: 10.1371/journal.pone.0184039

107. Ong J, van den Berg A, Faiz A, Boudewijn IM, Timens W, Vermeulen CJ, et al. Current smoking is associated with decreased expression of mir-335-5p in parenchymal lung fibroblasts. Int J Mol Sci (2019) 20:5176. doi: 10.3390/ ijms20205176

108. Tasena H, Boudewijn IM, Faiz A, Timens W, Hylkema MN, Berg M, et al. MiR-31-5p: A shared regulator of chronic mucus hypersecretion in asthma and chronic obstructive pulmonary disease. Allergy (2020) 75:703-6. doi: $10.1111 /$ all.14060

109. Xue H, Li MX. MicroRNA-150 protects against cigarette smoke-induced lung inflammation and airway epithelial cell apoptosis through repressing p53: MicroRNA-150 in CS-induced lung inflammation. Hum Exp Toxicol (2018) 37:920-8. doi: 10.1177/0960327117741749

110. Leuenberger C, Schuoler C, Bye H, Mignan C, Rechsteiner T, Hillinger S, et al. MicroRNA-223 controls the expression of histone deacetylase 2: a novel axis in COPD. J Mol Med (2016) 94:725-34. doi: 10.1007/s00109-016-1388-1

111. Dang X, Yang L, Guo J, Hu H, Li F, Liu Y, et al. miR-145-5p is associated with smoke-related chronic obstructive pulmonary disease via targeting KLF5. Chem Biol Interact (2019) 300:82-90. doi: 10.1016/j.cbi.2019.01.011

112. Lu L, Qi H, Luo F, Xu H, Ling M, Qin Y, et al. Feedback circuitry via let-7c between IncRNA CCAT1 and c-Myc is involved in cigarette smoke extractinduced malignant transformation of HBE cells. Oncotarget (2017) 8:1928597. doi: 10.18632/oncotarget.15195

113. Xu H, Ling M, Xue J, Dai X, Sun Q, Chen C, et al. Exosomal microRNA-21 derived from bronchial epithelial cells is involved in aberrant epitheliumfibroblast cross-talk in COPD induced by cigarette smoking. Theranostics (2018) 8:5419-33. doi: 10.7150/thno.27876

114. Lu L, Xu H, Yang P, Xue J, Chen C, Sun Q, et al. Involvement of HIF-1 $\alpha$ regulated miR-21, acting via the Akt/NF- $\mathrm{BB}$ pathway, in malignant transformation of HBE cells induced by cigarette smoke extract. Toxicol Lett (2018) 289:14-21. doi: 10.1016/j.toxlet.2018.02.027

115. He S, Li L, Sun S, Zeng Z, Lu J, Xie L. A novel murine chronic obstructive pulmonary disease model and the pathogenic role of microRNA-21. Front Physiol (2018) 9:503. doi: 10.3389/fphys.2018.00503

116. Zeng Z, He SY, Lu JJ, Liu C, Lin H, Xu CQ, et al. MicroRNA-21 aggravates chronic obstructive pulmonary disease by promoting autophagy. Exp Lung Res (2018) 44:89-97. doi: 10.1080/01902148.2018.1439548

117. Velasco-Torres Y, López VR, Pérez-Bautista O, Buendía-Roldan I, RamírezVenegas A, Pérez-Ramos J, et al. MiR-34a in serum is involved in mild-tomoderate COPD in women exposed to biomass smoke. BMC Pulm Med (2019) 19:227. doi: 10.1186/s12890-019-0977-5

118. Xie L, Wu M, Lin H, Liu C, Yang H, Zhan J, et al. An increased ratio of serum miR-21 to miR-181a levels is associated with the early pathogenic process of chronic obstructive pulmonary disease in asymptomatic heavy smokers. Mol Biosyst (2014) 10:1072-81. doi: 10.1039/c3mb70564a

119. Kim RY, Horvat JC, Pinkerton JW, Starkey MR, Essilfie AT, Mayall JR, et al. MicroRNA-21 drives severe, steroid-insensitive experimental asthma by amplifying phosphoinositide 3-kinase-mediated suppression of histone deacetylase 2. J Allergy Clin Immunol (2017) 139:519-32. doi: 10.1016/j.jaci.2016.04.038

120. Zhu QY, Liu Q, Chen JX, Lan K, Ge BX. MicroRNA-101 Targets MAPK Phosphatase-1 To Regulate the Activation of MAPKs in Macrophages. J Immunol (2010) 185:7435-42. doi: 10.4049/jimmunol.1000798

121. Wang B, Liu Y, Luo F, Xu Y, Qin Y, Lu X, et al. Epigenetic silencing of microRNA-218 via EZH2-mediated H3K27 trimethylation is involved in malignant transformation of HBE cells induced by cigarette smoke extract. Arch Toxicol (2016) 90:449-61. doi: 10.1007/s00204-014-1435-Z

122. Xu H, Sun Q, Lu L, Luo F, Zhou L, Liu J, et al. MicroRNA-218 acts by repressing TNFR1-mediated activation of NF- $\mathrm{KB}$, which is involved in MUC5AC hyperproduction and inflammation in smoking-induced bronchiolitis of COPD. Toxicol Lett (2017) 280:171-80. doi: 10.1016/j.toxlet.2017.08.079

123. Conickx G, Mestdagh P, Cobos FA, Verhamme FM, Maes T, Vanaudenaerde BM, et al. MicroRNA profiling reveals a role for MicroRNA-218-5p in the pathogenesis of chronic obstructive pulmonary disease. Am J Respir Crit Care Med (2017) 195:43-56. doi: 10.1164/rccm.201506-1182OC

124. Song J, Wang QH, Zou SC. Role of microRNA-218-5p in the pathogenesis of chronic obstructive pulmonary disease. Eur Rev Med Pharmacol Sci (2018) 22:4319-24. doi: 10.26355/eurrev_201807_15428
125. Mizuno S, Bogaard HJ, Gomez-Arroyo J, Alhussaini A, Kraskauskas D, Cool $\mathrm{CD}$, et al. MicroRNA-199a-5p is associated with hypoxia-inducible factor-1 $\alpha$ expression in lungs from patients with COPD. Chest (2012) 142:663-72. doi: 10.1378/chest.11-2746

126. Chatila WM, Criner GJ, Hancock WW, Akimova T, Moldover B, Chang JK, et al. Blunted expression of miR-199a-5p in regulatory $\mathrm{T}$ cells of patients with chronic obstructive pulmonary disease compared to unaffected smokers. Clin Exp Immunol (2014) 177:341-52. doi: 10.1111/cei.12325

127. Liu Y, Liu G, Zhang H, Wang J. MiRNA-199a-5p influences pulmonary artery hypertension via downregulating Smad3. Biochem Biophys Res Commun (2016) 473:859-66. doi: 10.1016/j.bbrc.2016.03.140

128. Halappanavar S, Nikota J, Wu D, Williams A, Yauk CL, Stampfli M. IL-1 Receptor Regulates microRNA-135b Expression in a Negative Feedback Mechanism during Cigarette Smoke-Induced Inflammation. J Immunol (2013) 190:3679-86. doi: 10.4049/jimmunol.1202456

129. Bertrams W, Griss K, Han M, Seidel K, Klemmer A, Sittka-Stark A, et al. Transcriptional analysis identifies potential biomarkers and molecular regulators in pneumonia and COPD exacerbation. Sci Rep (2020) 10:241. doi: 10.1038/s41598-019-57108-0

130. Dang X, Qu X, Wang W, Liao C, Li Y, Zhang X, et al. Bioinformatic analysis of microRNA and mRNA Regulation in peripheral blood mononuclear cells of patients with chronic obstructive pulmonary disease. Respir Res (2017) 18:4. doi: 10.1186/s12931-016-0486-5

131. Wang M, Huang Y, Liang Z, Liu D, Lu Y, Dai Y, et al. Plasma miRNAs might be promising biomarkers of chronic obstructive pulmonary disease. Clin Respir J (2016) 10:104-11. doi: 10.1111/crj.12194

132. Sundar IK, Li D, Rahman I. Small RNA-sequence analysis of plasma-derived extracellular vesicle miRNAs in smokers and patients with chronic obstructive pulmonary disease as circulating biomarkers. J Extracell Vesicles (2019) 8:1684816. doi: 10.1080/20013078.2019.1684816

133. Puig-Vilanova E, Martínez-Llorens J, Ausin P, Roca J, Gea J, Barreiro E. Quadriceps muscle weakness and atrophy are associated with a differential epigenetic profile in advanced COPD. Clin Sci (2015) 128:905-21. doi: $10.1042 / C S 20140428$

134. Sun Y, An N, Li J, Xia J, Tian Y, Zhao P, et al. miRNA-206 regulates human pulmonary microvascular endothelial cell apoptosis via targeting in chronic obstructive pulmonary disease. J Cell Biochem (2019) 120:6223-36. doi: $10.1002 /$ jcb. 27910

135. Chu H, Qu X, Wang F, Chang J, Cheng R, Song X, et al. MicroRNA-206 promotes lipopolysaccharide-induced inflammation injury via regulation of IRAK1 in MRC-5 cells. Int Immunopharmacol (2019) 73:590-8. doi: 10.1016/j.intimp.2019.05.029

136. Akbas F, Coskunpinar E, Aynaci E, Müsteri-Oltulu Y, Yildiz P. Analysis of Serum Micro-RNAs as potential biomarker in chronic obstructive pulmonary disease. Exp Lung Res (2012) 38:286-94. doi: 10.3109/01902148.2012.689088

137. Liu PF, Yan P, Zhao DH, Shi WF, Meng S, Liu Y, et al. The effect of environmental factors on the differential expression of miRNAs in patients with chronic obstructive pulmonary disease: A pilot clinical study. Int $J$ Chron Obstruct Pulmon Dis (2018) 13:741-51. doi: 10.2147/COPD.S156865

138. Lewis A, Riddoch-Contreras J, Natanek SA, Donaldson A, Man WDC, Moxham J, et al. Downregulation of the serum response factor/miR-1 axis in the quadriceps of patients with COPD. Thorax (2012) 67:26-34. doi: 10.1136/thoraxjnl-2011-200309

139. Oldenburger A, Van Basten B, Kooistra W, Meurs H, Maarsingh H, Krenning G, et al. Interaction between Epac1 and miRNA-7 in airway smooth muscle cells. Naunyn Schmiedebergs Arch Pharmacol (2014) 387:795-7. doi: 10.1007/s00210-014-1015-z

140. Savarimuthu-Francis SM, Davidson MR, Tan ME, Wright CM, Clarke BE, Duhig $\mathrm{EE}$, et al. MicroRNA-34c is associated with emphysema severity and modulates SERPINE1 expression. BMC Genomics (2014) 15:88. doi: 10.1186/1471-2164-15-88

141. Long YJ, Liu XP, Chen SS, Zong DD, Chen Y, Chen P. miR-34a is involved in CSE-induced apoptosis of human pulmonary microvascular endothelial cells by targeting Notch-1 receptor protein. Respir Res (2018) 19:21. doi: 10.1186/ s12931-018-0722-2

142. Kato R, Mizuno S, Kadowaki M, Shiozaki K, Akai M, Nakagawa K, et al. Sirt1 expression is associated with CD31 expression in blood cells from patients with chronic obstructive pulmonary disease. Respir Res (2016) 17:139. doi: 10.1186/s12931-016-0452-2 
143. Du Y, Ding Y, Chen X, Mei Z, Ding H, Wu Y, et al. MicroRNA-181c inhibits cigarette smoke-induced chronic obstructive pulmonary disease by regulating CCN1 expression. Respir Res (2017) 18:155. doi: 10.1186/s12931-017-0639-1

144. Faiz A, Steiling K, Roffel MP, Postma DS, Spira A, Lenburg ME, et al. Effect of long-term corticosteroid treatment on microRNA and gene-expression profiles in COPD. Eur Respir J (2019) 53:1801202. doi: 10.1183/13993003.01202-2018

145. Rodrigo-Muñoz JM, Rial MJ, Sastre B, Cañas JA, Mahíllo-Fernández I, Quirce S, et al. Circulating miRNAs as diagnostic tool for discrimination of respiratory disease: Asthma, asthma-chronic obstructive pulmonary disease (COPD) overlap and COPD. Allergy Eur J Allergy Clin Immunol (2019) 74:2491-4. doi: 10.1111/all.13916

146. O’Leary L, Sevinç K, Papazoglou IM, Tildy B, Detillieux K, Halayko AJ, et al. Airway smooth muscle inflammation is regulated by microRNA-145 in COPD. FEBS Lett (2016) 590:1324-34. doi: 10.1002/1873-3468.12168

147. Yang S, Cui H, Xie N, Icyuz M, Banerjee S, Antony VB, et al. MiR-145 regulates myofibroblast differentiation and lung fibrosis. FASEB J (2013) 27:2382-91. doi: 10.1096/fj.12-219493

148. Dutta RK, Chinnapaiyan S, Rasmussen L, Raju SV, Unwalla HJ. A Neutralizing Aptamer to TGFBR2 and miR-145 Antagonism Rescue Cigarette Smoke- and TGF- $\beta$-Mediated CFTR Expression. Mol Ther (2019) 27:442-55. doi: 10.1016/j.ymthe.2018.11.017

149. Perry MM, Moschos SA, Williams AE, Shepherd NJ, Larner-Svensson HM, Lindsay MA. Rapid Changes in MicroRNA-146a Expression Negatively Regulate the IL-1ß-Induced Inflammatory Response in Human Lung Alveolar Epithelial Cells. J Immunol (2008) 180:5689-98. doi: 10.4049/ jimmunol.180.8.5689

150. Stolzenburg LR, Wachtel S, Dang H, Harris A. MIR-1343 attenuates pathways of fibrosis by targeting the TGF- $\beta$ receptors. Biochem J (2016) 473:245-56. doi: 10.1042/BJ20150821

151. Mercer BA, Kolesnikova N, Sonett J, D’Armiento J. Extracellular Regulated Kinase/Mitogen Activated Protein Kinase Is Up-regulated in Pulmonary Emphysema and Mediates Matrix Metalloproteinase-1 Induction by Cigarette Smoke. J Biol Chem (2004) 279:17690-6. doi: 10.1074/jbc.M313842200

152. Tang K, Zhao J, Xie J, Wang J. Decreased miR-29b expression is associated with airway inflammation in chronic obstructive pulmonary disease. Am J Physiol Lung Cell Mol Physiol (2019) 316:L621-9. doi: 10.1152/ajplung.00436.2018

153. Shi L, Xin Q, Chai R, Liu L, Ma Z. Ectopic expressed miR-203 contributes to chronic obstructive pulmonary disease via targeting TAK1 and PIK3CA. Int J Clin Exp Pathol (2015) 8:10662-70.

154. Wang R, Li M, Zhou S, Zeng D, Xu X, Xu R, et al. Effect of a single nucleotide polymorphism in miR-146a on COX-2 protein expression and lung function in smokers with chronic obstructive pulmonary disease. Int J Chron Obstruct Pulmon Dis (2015) 10:463-73. doi: 10.2147/COPD.S74345

155. Fawzy MS, Hussein MH, Abdelaziz EZ, Yamany HA, Ismail HM, Toraih EA. Association of microRNA-196a2 variant with response to short-acting $\beta 2$ agonist in COPD: An Egyptian pilot study. PloS One (2016) 11:e0152834. doi: 10.1371/journal.pone.0152834

156. Li LJ, Gao LB, Lv ML, Dong W, Su XW, Liang WB, et al. Association between SNPs in pre-miRNA and risk of chronic obstructive pulmonary disease. Clin Biochem (2011) 44:813-6. doi: 10.1016/j.clinbiochem.2011.04.021

157. Zhou S, Liu Y, Li M, Wu P, Sun G, Fei G, et al. Combined effects of PVT1 and MiR-146a single nucleotide polymorphism on the lung function of smokers with chronic obstructive pulmonary disease. Int J Biol Sci (2018) 14:1153-62. doi: $10.7150 /$ ijbs. 25420

158. Shen Z, Tang W, Guo J, Sun S. MiR-483-5p plays a protective role in chronic obstructive pulmonary disease. Int J Mol Med (2017) 40:193-200. doi: $10.3892 / \mathrm{ijmm} .2017 .2996$

159. Izzotti A, Larghero P, Longobardi M, Cartiglia C, Camoirano A, Steele VE, et al. Dose-responsiveness and persistence of microRNA expression alterations induced by cigarette smoke in mouse lung. Mutat Res (2011) 717:9-16. doi: 10.1016/j.mrfmmm.2010.12.008

160. Shen W, Liu J, Zhao G, Fan M, Song G, Zhang Y, et al. Repression of toll-like receptor-4 by microRNA-149-3p is associated with smoking-related COPD. Int J Chron Obstruct Pulmon Dis (2017) 12:705-15. doi: 10.2147/COPD.S128031

161. Shen W, Liu J, Fan M, Wang S, Zhang Y, Wen L, et al. MiR-3202 protects smokers from chronic obstructive pulmonary disease through inhibiting FAIM2: An in vivo and in vitro study. Exp Cell Res (2018) 362:370-7. doi: 10.1016/j.yexcr.2017.11.038
162. Lewis CE, Harney AS, Pollard JW. The Multifaceted Role of Perivascular Macrophages in Tumors. Cancer Cell (2016) 30:18-25. doi: 10.1016/ j.ccell.2016.05.017

163. Lu L, Luo F, Liu Y, Liu X, Shi L, Lu X, et al. Posttranscriptional silencing of the IncRNA MALAT1 by miR-217 inhibits the epithelial-mesenchymal transition via enhancer of zeste homolog 2 in the malignant transformation of HBE cells induced by cigarette smoke extract. Toxicol Appl Pharmacol (2015) 289:276-85. doi: 10.1016/j.taap.2015.09.016

164. Dino P, D'Anna C, Sangiorgi C, Di Sano C, Di Vincenzo S, Ferraro M, et al. Cigarette smoke extract modulates E-Cadherin, Claudin-1 and miR-21 and promotes cancer invasiveness in human colorectal adenocarcinoma cells. Toxicol Lett (2019) 317:102-9. doi: 10.1016/j.toxlet.2019.09.020

165. Zhong S, Chen C, Liu N, Yang L, Hu Z, Duan P, et al. Overexpression of hsamiR-664a-3p is associated with cigarette smoke-induced chronic obstructive pulmonary disease via targeting FHL1. Int J Chron Obstruct Pulmon Dis (2019) 14:2319-29. doi: 10.2147/COPD.S224763

166. Baker JR, Vuppusetty C, Colley T, Papaioannou AI, Fenwick P, Donnelly L, et al. Oxidative stress dependent microRNA-34a activation via PI3Ko reduces the expression of sirtuin-1 and sirtuin-6 in epithelial cells. Sci Rep (2016) 6:35871. doi: 10.1038/srep35871

167. Wu Y, Guan S, Ge Y, Yang Y, Cao Y, Zhou J. Cigarette smoke promotes chronic obstructive pulmonary disease (COPD) through the miR-130a/ Wnt1 axis. Toxicol In Vitro (2020) 65:104770. doi: 10.1016/j.tiv.2020.104770

168. Zhao Y, Xu Y, Li Y, Xu W, Luo F, Wang B, et al. NF- $\kappa B-m e d i a t e d$ Inflammation Leading to EMT via miR-200c Is Involved in Cell Transformation Induced by Cigarette Smoke Extract. Toxicol Sci (2013) 135:265-76. doi: 10.1093/toxsci/kft150

169. Lin L, Sun J, Wu D, Lin D, Sun D, Li Q, et al. MicroRNA-186 is associated with hypoxia-inducible factor- $1 \alpha$ expression in chronic obstructive pulmonary disease. Mol Genet Genomic Med (2019) 7:e531. doi: 10.1002/mgg3.531

170. Hassan T, Carroll TP, Buckley PG, Cummins R, O’Neill SJ, McElvaney NG, et al. MiR-199a-5p silencing regulates the unfolded protein response in chronic obstructive pulmonary disease and $\alpha 1$-antitrypsin deficiency. Am J Respir Crit Care Med (2014) 189:263-73. doi: 10.1164/rccm.201306-1151OC

171. Oldenburger A, Roscioni SS, Jansen E, Menzen MH, Halayko AJ, Timens W, et al. Anti-inflammatory role of the cAMP effectors Epac and PKA: Implications in chronic obstructive pulmonary disease. PloS One (2012) 7: e31574. doi: 10.1371/journal.pone.0031574

172. Ong J, Faiz A, Timens W, van den Berge M, Terpstra MM, Kok K, et al. Marked TGF- $\beta$-regulated miRNA expression changes in both COPD and control lung fibroblasts. Sci Rep (2019) 9:18214. doi: 10.1038/s41598-019$54728-4$

173. Wang Y, Yang L, Li P, Huang H, Liu T, He H, et al. Circulating microRNA signatures associated with childhood asthma. Clin Lab (2015) 61:467-74. doi: 10.7754/Clin.Lab.2014.141020

174. Mousavi SR, Ahmadi A, Jamalkandi SA, Salimian J. Involvement of microRNAs in physiological and pathological processes in asthma. J Cell Physiol (2019) 234:21547-59. doi: 10.1002/jcp.28781

175. Leidinger $\mathrm{P}$, Keller A, Borries A, Huwer H, Rohling M, Huebers J, et al. Specific peripheral miRNA profiles for distinguishing lung cancer from COPD. Lung Cancer (2011) 74:41-7. doi: 10.1016/j.lungcan.2011.02.003

176. Li L, Feng T, Zhang W, Gaon S, Wang R, Lv W. MicroRNA Biomarker hsamiR-195-5p for Detecting the Risk of Lung Cancer. Int J Genomics (2020) 2020:7415909. doi: 10.1155/2020/7415909

177. Simpson LJ, Patel S, Bhakta NR, Choy DF, Brightbill HD, Ren X, et al. A microRNA upregulated in asthma airway $\mathrm{T}$ cells promotes $\mathrm{T}$ H 2 cytokine production. Nat Immunol (2014) 15:1162-70. doi: 10.1038/ni.3026

178. Lu TX, Hartner J, Lim EJ, Fabry V, Mingler MK, Cole ET, et al. MicroRNA-21 Limits In Vivo Immune Response-Mediated Activation of the IL-12/IFN- $\gamma$ Pathway, Th1 Polarization, and the Severity of Delayed-Type Hypersensitivity. J Immunol (2011) 187:3362-73. doi: 10.4049/jimmunol.1101235

179. Perry MM, Adcock IM, Chung KF. Role of microRNAs in allergic asthma: Present and future. Curr Opin Allergy Clin Immunol (2015) 15:156-62. doi: 10.1097/ACI.0000000000000147

180. Walker JA, McKenzie ANJ. TH2 cell development and function. Nat Rev Immunol (2018) 18:121-33. doi: 10.1038/nri.2017.118

181. Steiner DF, Thomas MF, Hu JK, Yang Z, Babiarz JE, Allen CDC, et al. MicroRNA-29 Regulates T-Box Transcription Factors and Interferon- $\gamma$ 
Production in Helper T Cells. Immunity (2011) 35:169-81. doi: 10.1016/ j.immuni.2011.07.009

182. Yan J, Zhang X, Sun S, Yang T, Yang J, Wu G, et al. MiR-29b Reverses T helper 1 cells/T helper 2 cells Imbalance and Alleviates Airway Eosinophils Recruitment in OVA-Induced Murine Asthma by Targeting Inducible CoStimulator. Int Arch Allergy Immunol (2019) 180:182-94. doi: 10.1159/ 000501686

183. Alharris E, Alghetaa H, Seth R, Chatterjee S, Singh NP, Nagarkatti M, et al. Resveratrol Attenuates Allergic Asthma and Associated Inflammation in the Lungs Through Regulation of miRNA-34a That Targets FoxP3 in Mice. Front Immunol (2018) 9:2992. doi: 10.3389/fimmu.2018.02992

184. Girodet PO, Nguyen D, Mancini JD, Hundal M, Zhou X, Israel E, et al. Alternative macrophage activation is increased in asthma. Am J Respir Cell Mol Biol (2016) 55:467-75. doi: 10.1165/rcmb.2015-0295OC

185. Draijer C, Robbe P, Boorsma CE, Hylkema MN, Melgert BN. Dual role of YM1+ M2 macrophages in allergic lung inflammation. Sci Rep (2018) 8:5105. doi: 10.1038/s41598-018-23269-7

186. Feketea G, Bocsan CI, Popescu C, Gaman M, Stanciu LA, Zdrenghea MT. A Review of Macrophage MicroRNAs' Role in Human Asthma. Cells (2019) 8:420. doi: $10.3390 /$ cells 8050420

187. Peng L, Zhang H, Hao Y, Xu F, Yang J, Zhang R, et al. Reprogramming macrophage orientation by microRNA 146b targeting transcription factor IRF5. EBioMedicine (2016) 14:83-96. doi: 10.1016/j.ebiom.2016.10.041

188. Huang C, Liu XJ, Qun Z, Xie J, Ma TT, Meng XM, et al. MiR-146a modulates macrophage polarization by inhibiting Notch1 pathway in RAW264.7 macrophages. Int Immunopharmacol (2016) 32:46-54. doi: 10.1016/ j.intimp.2016.01.009

189. Athari SS. Targeting cell signaling in allergic asthma. Signal Transduct Target Ther (2019) 4:45. doi: 10.1038/s41392-019-0079-0

190. Davies DE. The role of the epithelium in airway remodeling in asthma. Proc Am Thorac Soc (2009) 6:678-82. doi: 10.1513/pats.200907-067DP

191. Wang LQ, Wang CL, Xu LN, Hua DF. The Expression Research of miR-210 in the Elderly Patients With COPD Combined With Ischemic Stroke. Eur Rev MEd Pharmacol Sci (2016) 20:4756-60.

192. Global Initiative For Chronic Obstructive Lung Disease. Diagnosis of Diseases of Chronic Airflow Limitation: Asthma, COPD and Asthma-COPD Overlap Syndrome (ACOS) (2015). Available at: www.ginasthma.orgwww.goldcopd. orghttp://www.ginasthma.orggoldreportsareavailableathttp//www.goldcopd.org (Accessed April 14, 2020).

193. Cosío BG, De Llano LP, Viña AL, Torrego A, Lopez-Campos JL, Soriano JB, et al. Th-2 signature in chronic airway diseases: Towards the extinction of asthma-COPD overlap syndrome? Eur Respir J (2017) 49:1602397. doi: $10.1183 / 13993003.02397-2016$

194. Asensio VJ, Tomás A, Iglesias A, de Llano LP, del Pozo V, Cosío BG. Eosinophilic COPD Patients Display a Distinctive Serum miRNA Profile From Asthma and Non-eosinophilic COPD. Arch Bronconeumol (2019) 56:234-41. doi: 10.1016/j.arbres.2019.09.020

195. Mukherjee M, Svenningsen S, Nair P. Glucocortiosteroid subsensitivity and asthma severity. Curr Opin Pulm Med (2017) 23:78-88. doi: 10.1097/ MCP. 0000000000000337

196. Zhou H, Li J, Gao P, Wang Q, Zhang J. miR-155: A novel target in allergic asthma. Int J Mol Sci (2016) 17:1773. doi: 10.3390/ijms17101773

197. Wang ZH, Liang YB, Tang H, Chen ZB, Li ZY, Hu XC, et al. Dexamethasone down-regulates the expression of microRNA-155 in the livers of septic mice. PloS One (2013) 8:e80547. doi: 10.1371/journal.pone.0080547

198. Zheng Y, Xiong S, Jiang P, Liu R, Liu X, Qian J, et al. Glucocorticoids inhibit lipopolysaccharide-mediated inflammatory response by downregulating microRNA-155: A novel anti-inflammation mechanism. Free Radic Biol Med (2012) 52:1307-17. doi: 10.1016/j.freeradbiomed.2012.01.031

199. Li J, Panganiban R, Kho AT, McGeachie MJ, Farnam L, Chase RP, et al. Circulating MicroRNAs and Treatment Response in Childhood Asthma. Am J Respir Crit Care Med (2020) 202:65-72. doi: 10.1164/rccm.201907-1454oc

200. Elbehidy RM, Youssef DM, El-Shal AS, Shalaby SM, Sherbiny HS, Sherief LM, et al. MicroRNA-21 as a novel biomarker in diagnosis and response to therapy in asthmatic children. Mol Immunol (2016) 71:107-14. doi: 10.1016/ j.molimm.2015.12.015
201. Wu SQ, Wang GL, Li LY, Ji J. Effects of microRNA-21 on the interleukin 12/ signal transducer and activator of transcription 4 signaling pathway in asthmatic mice. Cent Eur J Immunol (2014) 39:40-5. doi: 10.5114/ceji.2014.42121

202. Sheedy FJ, Palsson-Mcdermott E, Hennessy EJ, Martin C, O'Leary JJ, Ruan Q, et al. Negative regulation of TLR4 via targeting of the proinflammatory tumor suppressor PDCD4 by the microRNA miR-21. Nat Immunol (2010) 11:141-7. doi: 10.1038/ni.1828

203. Lu LF, Liston A. MicroRNA in the immune system, microRNA as an immune system. Immunology (2009) 127:291-8. doi: 10.1111/j.13652567.2009.03092.x

204. Li JJ, Tay HL, Maltby S, Xiang Y, Eyers F, Hatchwell L, et al. MicroRNA-9 regulates steroid-resistant airway hyperresponsiveness by reducing protein phosphatase 2A activity. J Allergy Clin Immunol (2015) 136:462-73. doi: $10.1016 /$ j.jaci.2014.11.044

205. McGeachie MJ, Davis JS, Kho AT, Dahlin A, Sordillo JE, Sun M, et al. Asthma remission: Predicting future airways responsiveness using an miRNA network. J Allergy Clin Immunol (2017) 140:598-600. doi: 10.1016/j.jaci.2017.01.023

206. Williams AE, Larner-Svensson H, Perry MM, Campbell GA, Herrick SE, Adcock IM, et al. MicroRNA expression profiling in mild asthmatic human airways and effect of corticosteroid therapy. PloS One (2009) 4:e5889. doi: 10.1371/journal.pone.0005889

207. World Health Organization. COPD management (2013). Available at: https://www.who.int/respiratory/copd/management/en/ (Accessed Accesed 18 April, 2020).

208. Lopez-Campos JL, Carrasco Hernández L, Muñoz X, Bustamante V, Barreiro E. Current controversies in the stepping up and stepping down of inhaled therapies for COPD at the patient level. Respirology (2018) 23:818-27. doi: 10.1111/ resp. 13341

209. Barnes PJ. Targeting the epigenome in the treatment of asthma and chronic obstructive pulmonary disease. Proc Am Thorac Soc (2009) 6:693-6. doi: 10.1513/pats.200907-071DP

210. Liu S, Liu M, Dong L. The clinical value of lncRNA MALAT1 and its targets miR-125b, miR-133, miR-146a, and miR-203 for predicting disease progression in chronic obstructive pulmonary disease patients. J Clin Lab Anal (2020) 34:e23410. doi: 10.1002/jcla.23410

211. Xu W, Wang Y, Ma Y, Yang J. MiR-223 plays a protecting role in neutrophilic asthmatic mice through the inhibition of NLRP3 inflammasome. Respir Res (2020) 21:116. doi: 10.1186/s12931-020-01374-4

212. Liu J, Chen Y, Zhang F, Peng X, Mao X, Lu W, et al. Divergent Roles of miR$3162-3 p$ in Pulmonary Inflammation in Normal and Asthmatic Mice as well as Antagonism of miR-3162-3p in Asthma Treatment. Int Arch Allergy Immunol (2020) 181:594-605. doi: 10.1159/000507250

213. Cullinan P, Reid P. Pneumoconiosis. Prim Care Respir J (2013) 22:249-52. doi: $10.4104 /$ pcri.2013.00055

214. Wang X, Lu X, Ma C, Ma L, Han S. Combination of TLR agonist and miR146a mimics attenuates ovalbumin-induced asthma. Mol Med (2020) 26:65. doi: 10.1186/s10020-020-00191-1

215. Shi ZG, Sun Y, Wang KS, Jia JD, Yang J, Li YN. Effects of mir-26a/mir-146a/ miR-31 on airway inflammation of asthma mice and asthma children. Eur Rev Med Pharmacol Sci (2019) 23:5432-40. doi: 10.26355/eurre

Conflict of Interest: VP has received honoraria (advisory board, speaker) and/or institutional grant/research support from Astra-Zeneca and GSK.

The remaining authors declare that the research was conducted in the absence of any commercial or financial relationships that could be construed as a potential conflict of interest.

Copyright (c) 2021 Cañas, Rodrigo-Muñoz, Sastre, Gil-Martinez, Redondo and del Pozo. This is an open-access article distributed under the terms of the Creative Commons Attribution License (CC BY). The use, distribution or reproduction in other forums is permitted, provided the original author(s) and the copyright owner(s) are credited and that the original publication in this journal is cited, in accordance with accepted academic practice. No use, distribution or reproduction is permitted which does not comply with these terms. 